\title{
Secretome Analysis of Arabidopsis-Trichoderma atroviride Interaction Unveils New Roles for the Plant Glutamate:Glyoxylate Aminotransferase GGAT1 in Plant Growth Induced by the Fungus and Resistance against Botrytis cinerea
}

\author{
María del Carmen González-López ${ }^{1,+}$, Saúl Jijón-Moreno ${ }^{1,+}{ }^{+}$, Mitzuko Dautt-Castro ${ }^{1}$ (D), \\ Cesaré Ovando-Vázquez ${ }^{1,2}(\mathbb{D})$, Tamar Ziv ${ }^{3}$, Benjamin A. Horwitz ${ }^{4}$ and Sergio Casas-Flores ${ }^{1, *(D)}$
}

Citation: González-López, M.d.C.; Jijón-Moreno, S.; Dautt-Castro, M.; Ovando-Vázquez, C.; Ziv, T.; Horwitz, B.A.; Casas-Flores, $\mathrm{S}$. Secretome Analysis of Arabidopsis-Trichoderma atroviride Interaction Unveils New Roles for the Plant Glutamate:Glyoxylate Aminotransferase GGAT1 in Plant Growth Induced by the Fungus and Resistance against Botrytis cinerea. Int J. Mol. Sci. 2021, 22, 6804. https:// doi.org/10.3390/ijms22136804

Academic Editors: Vijai Kumar Gupta, Jiri Damborsky, Gustavo Molina, Kumar Vivek and Zeba Usmani

Received: 13 May 2021

Accepted: 10 June 2021

Published: 24 June 2021

Publisher's Note: MDPI stays neutral with regard to jurisdictional claims in published maps and institutional affiliations.

Copyright: (c) 2021 by the authors. Licensee MDPI, Basel, Switzerland. This article is an open access article distributed under the terms and conditions of the Creative Commons Attribution (CC BY) license (https:// creativecommons.org/licenses/by/ $4.0 /)$.
1 Laboratorio de Genómica Funcional y Comparativa, División de Biología Molecular, IPICYT, Camino a la Presa San José No. 2055. Col. Lomas 4a. Section, San Luis Potosí C.P. 78216, Mexico; maria.gonzalez@ipicyt.edu.mx (M.d.C.G.-L.); saul.jijon@ipicyt.edu.mx (S.J.-M.); mitzuko.dautt@ipicyt.edu.mx (M.D.-C.); cesare.ovando@ipicyt.edu.mx (C.O.-V.)

2 Centro Nacional de Supercómputo, IPICYT, Camino a la Presa San José No. 2055. Col. Lomas 4ª Section, San Luis Potosí C.P. 78216, Mexico

3 Smoler Protein Center, Faculty of Biology, Technion-Israel Institute of Technology, Haifa 32000, Israel; tamarz@technion.ac.il

4 Faculty of Biology, Technion-Israel Institute of Technology, Haifa 32000, Israel; horwitz@technion.ac.il

* Correspondence: scasas@ipicyt.edu.mx; Tel.: +52-444-834-2046

+ These authors contributed equally to this work.

\begin{abstract}
The establishment of plant-fungus mutualistic interaction requires bidirectional molecular crosstalk. Therefore, the analysis of the interacting organisms secretomes would help to understand how such relationships are established. Here, a gel-free shotgun proteomics approach was used to identify the secreted proteins of the plant Arabidopsis thaliana and the mutualistic fungus Trichoderma atroviride during their interaction. A total of 126 proteins of Arabidopsis and 1027 of T. atroviride were identified. Among them, 118 and 780 were differentially modulated, respectively. Bioinformatic analysis unveiled that both organisms' secretomes were enriched with enzymes. In T. atroviride, glycosidases, aspartic endopeptidases, and dehydrogenases increased in response to Arabidopsis. Additionally, amidases, protein-serine/threonine kinases, and hydro-lyases showed decreased levels. Furthermore, peroxidases, cysteine endopeptidases, and enzymes related to the catabolism of secondary metabolites increased in the plant secretome. In contrast, pathogenesis-related proteins and protease inhibitors decreased in response to the fungus. Notably, the glutamate:glyoxylate aminotransferase GGAT1 was secreted by Arabidopsis during its interaction with T. atroviride. Our study showed that GGAT1 is partially required for plant growth stimulation and on the induction of the plant systemic resistance by T. atroviride. Additionally, GGAT1 seems to participate in the negative regulation of the plant systemic resistance against $B$. cinerea through a mechanism involving $\mathrm{H}_{2} \mathrm{O}_{2}$ production.
\end{abstract}

Keywords: Arabidopsis; Trichoderma; secretome; enzymes; glycosidases; GGAT1; plant growth; induced systemic resistance; hydrogen peroxide

\section{Introduction}

In their natural settings, plants interact with a plethora of microorganisms, including bacteria, oomycetes, and fungi, through dynamic interactions ranging from parasitism to mutualism [1]. Plants restrict the access of invading microorganisms through mechanical structural barriers such as cell walls, waxes, and trichomes [2]. Furthermore, plants can detect invaders responding with the accumulation of toxic chemical compounds including 
alkaloids, phenols, terpenoids, and glucosinolates [3]. Phytopathogens secrete an array of lytic enzymes into the extracellular space to degrade the cell wall polymers including cellulose, xylan, and pectin to surpass the plant cell wall $[4,5]$.

Once pathogens overcome the plant's physical and chemical barriers, they are recognized through inducible defense mechanisms, including the perception of their highly conserved pathogen- or microbe-associated molecular patterns (PAMPs or MAMPs) [6]. This perception is carried out by membrane-associated receptors, called pattern recognition receptors (PRRs), which lead to the activation of the first layer of defense, termed PAMP-triggered immunity (PTI) that wards off invading microorganisms [7,8]. Successful pathogens secrete a repertoire of effector molecules, some of which are delivered into the plant cell facilitating the infection [9]. Intracellular effectors interfere with immune signaling leading to the so-called effector-triggered susceptibility (ETS). Nevertheless, plants have developed strategies to to directly or indirectly detect effectors through intracellular receptors termed nucleotide-binding, leucine-rich repeat receptors (NLRs). Consequently, the plant cells activate a second layer of defense named effector-triggered immunity (ETI), which is generally associated with the hypersensitive response (HR) [6]. The stimulation of PTI leads to the activation of several physiological events, such as the accumulation of reactive oxygen species (ROS), callose deposition, biosynthesis of antimicrobial metabolites, and the production of a complex blend of phytohormones, including salicylic acid (SA), jasmonate (JA), and ethylene (ET), among others, which act as signaling molecules $[2,10]$. Upon local activation of PTI or ETI, some of two forms of systemic resistance are activated in the plant: systemic acquired resistance (SAR) and induced systemic resistance (ISR). SAR signaling is dependent on SA and is involved in defense against biotrophic and hemibiotrophic pathogens (i.e., Pseudomonas syringae). ISR requires JA and ET as signaling molecules, and it is involved in response against necrotrophic microorganisms (i.e., Botrytis cinerea), herbivores [10], and beneficial microbes [6].

During plant-microbe interaction, plants secrete an array of proteins to the extracellular space, which is commonly referred to as the apoplast, where they participate in cell wall structure maintenance and potentially in the establishment of a molecular dialog with the invaders, leading to different types of relationships [11]. The whole set of proteins secreted by the host plant or its microbial partner constitutes their so-called secretome, whose constituent proteins are secreted at a particular time by known or unknown mechanisms of transport [11]. Many of these proteins are conventionally transported through the endoplasmic reticulum (ER) to the Golgi and then to the plasma membrane, where they are finally secreted into the apoplast. Conventionally secreted proteins contain an N-terminal signal peptide (SP). Proteins that lack an SP reach the extracellular space using unconventional protein secretion (UPS) pathways [12]. Some proteins secreted by UPS do so by a non-vesicular means of transport, bypassing the Golgi. Thus, proteins are directly secreted and translocated across the plasma membrane [12]. Other means of transport by UPS depend on specific intracellular compartments including vacuoles and exocyst-positive organelle (EXPO) [13].

Mutualistic fungi provide multiple benefits to their host plants, such as stimulation of plant growth and protection against abiotic and biotic stresses $[14,15]$. Some examples of mutualistic fungi include the mycorrhizal fungi Glomus intraradices and Laccaria bicolor and the plant growth-promoting fungi Trichoderma spp. [14-16]. Trichoderma spp. are filamentous ascomycetes found as free-living microorganisms growing on decomposed organic matter. Members of this genus colonize the roots of a broad range of plants [15]. The mechanisms by which Trichoderma may influence plant growth include the synthesis of phytohormones [17], the solubilization of phosphate [18], and the production of secondary metabolites $[19,20]$. Furthermore, plants colonized by Trichoderma spp. induce the SAR and ISR simultaneously and transiently, mounting a physiological phenomenon called priming [21]. Priming is characterized by an enhanced activation of induced defense mechanisms at distal parts of the infection, resulting in a faster and more effective response upon a second infection by phytopathogens $[15,22,23]$. Furthermore, Trichoderma spp. 
induce the expression of genes related to defense, such as the plant defensin 1.2 gene $(P D F 1.2)$ and the pathogenesis-related 1a gene (PR-1a), which are used as markers for ISR-priming and SAR, respectively [19,22-25]. In addition, some proteins of Trichoderma spp. (i.e., small-secreted cysteine-rich proteins (sm1), cellulases (Thp1 and Thp2), xylanases (Xyn2/Eix)) and volatile organic compounds (i.e., 6-pentyl-2H-pyran-2-one, 2-heptanone, 3 -octanol) act as elicitors of plant defense responses $[15,19,21]$. These findings, along with results derived from our research group (unpublished data), indicate that Trichoderma is initially recognized as a pathogen, later suppressing the plant immunity to establish a mutualistic association with its host plant [23].

Proteomic studies have provided of new insights into the molecular crosstalk that occurs between Trichoderma spp. and their host plant. For instance, T. virens secretes an array of proteins potentially involved in cell-wall degradation, scavenging of ROS and secondary metabolism during its interaction with maize plants [26,27]. In response to T. virens, maize plants secrete into the apoplast proteins related to defense, including proteinase inhibitors and PR proteins [26]. Interestingly, Arabidopsis secretes photosynthetic proteins, including the glutamate:glyoxylate aminotransferase 1 protein, GGAT1, in extracellular vesicles (EVs) [28]. However, the role of most of these proteins in the establishment of a mutualistic relationship between both organisms remains unclear.

Here, to unravel the possible role of $A$. thaliana (hereafter referred to as Arabidopsis) and Trichoderma atroviride secreted enzymes in the establishment of a mutualistic relationship, their secretomes were assessed at different times of interaction. Arabidopsis and T. atroviride were grown alone or in co-culture in a semi-hydroponic system, their secretomes were obtained, and their secreted proteins were identified by liquid chromatography-tandem mass spectrometry (LC-MS/MS). Subsequently, a quantitative proteomic analysis was performed to identify the differentially accumulated proteins of both organisms. Furthermore, several bioinformatics tools were used to predict the protein functions that potentially take part in the establishment of such mutualistic association. Finally, GGAT1, which was differentially accumulated, was chosen to assess its role in plant growth stimulation and in the triggering of systemic resistance by T. atroviride against the phytopathogenic fungus B. cinerea.

\section{Results}

\subsection{Time-Course Analysis of the Arabidopsis-T. atroviride Interaction Secretome}

To dissect the repertoire of proteins secreted by Arabidopsis and T. atroviride during their interaction in a semi-hydroponic system at 24, 48, and $96 \mathrm{~h}$ of co-culture (Figure S1), samples of two independent biological replicates were analyzed by LC-MS/MS. A total of 1153 proteins were identified. Mapping of the predicted peptides showed that 1027 proteins pertained to the fungus, whereas 126 belonged to the plant (Table S1).

Furthermore, we analyzed the secretomes changes to identify proteins that potentially could be involved in the establishment of the interaction at early ( 24 and $48 \mathrm{~h}$ ) and late (96 h) times. The Arabidopsis or T. atroviride proteins were filtered to include only those classified as differentially accumulated $\left(\log _{2} \geq 2.0\right.$ or $\left.\leq-2.0\right)$ with a false discovery rate (FDR) $<0.01$, compared to Arabidopsis or T. atroviride controls growing alone. Furthermore, the differentially accumulated proteins must be present in at least one of the three-time points of co-culture in both biological replicates. Accordingly, 118 proteins of Arabidopsis were differentially accumulated, of which 78 increased whereas 40 decreased. On the T. atroviride side, 780 proteins were differentially accumulated, of which 477 increased, whereas 303 decreased (Table S2). As shown in Figure 1, most Arabidopsis and T. atroviride proteins were differentially modulated at 48 and $96 \mathrm{~h}$ of co-culture, respectively. 


\section{Number of proteins}

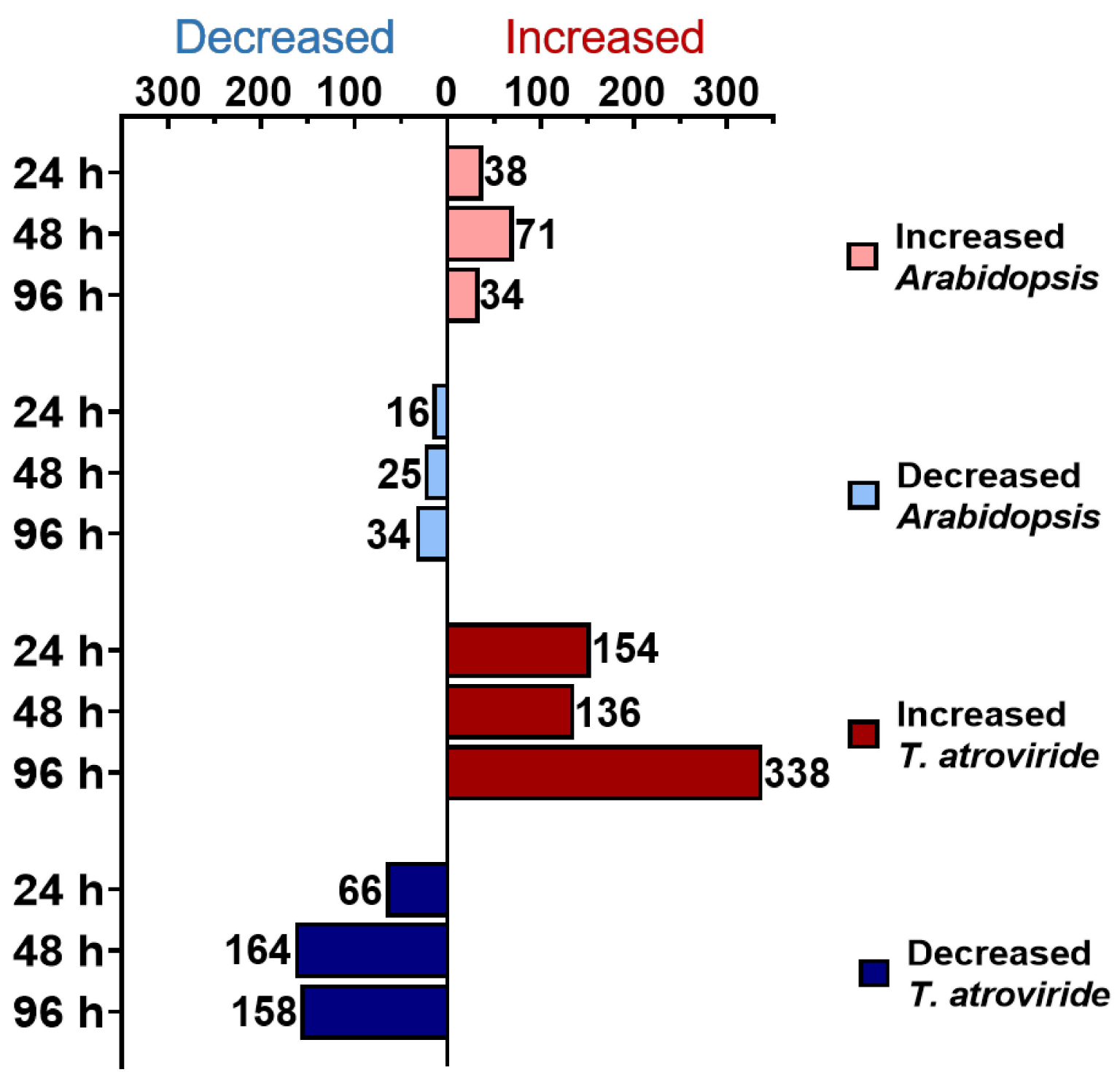

Figure 1. Arabidopsis and T. atroviride secreted proteins were differentially modulated mainly at 48 and $96 \mathrm{~h}$ of co-culture, respectively. Differential accumulation of $A$. thaliana and T. atroviride proteins during their interaction at 24, 48 , and $96 \mathrm{~h}$ of co-culture. The Arabidopsis or T. atroviride proteins were classified as differentially expressed based on $\log _{2} \geq 2.0$ for increased and $\leq-2.0$ for decreased (with an FDR $<0.01$ ) compared to their respective controls growing alone. Labels for each bar indicate the number of proteins.

To determinate the common and unique proteins of Arabidopsis and T. atroviride with increased or decreased abundance over time, they were grouped using Venn diagrams. Only $20(25.6 \%)$ of the increased and nine (22.5\%) of the decreased proteins from Arabidopsis overlapped at all times of interaction (Figure 2A). In the T. atroviride secretome, only 24 (5\%) of the increased and $10(3.3 \%)$ of the decreased proteins overlapped at all times of co-culture, while unique proteins at each time analyzed were more at specific time points (Figure 2B). 
A

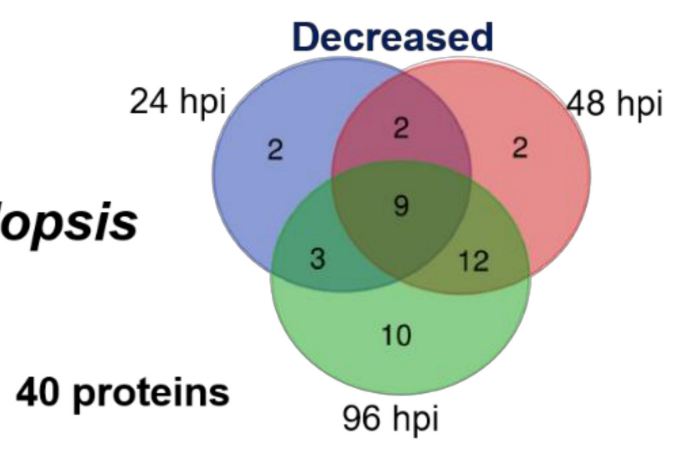

\title{
Arabidopsis
}

40 proteins

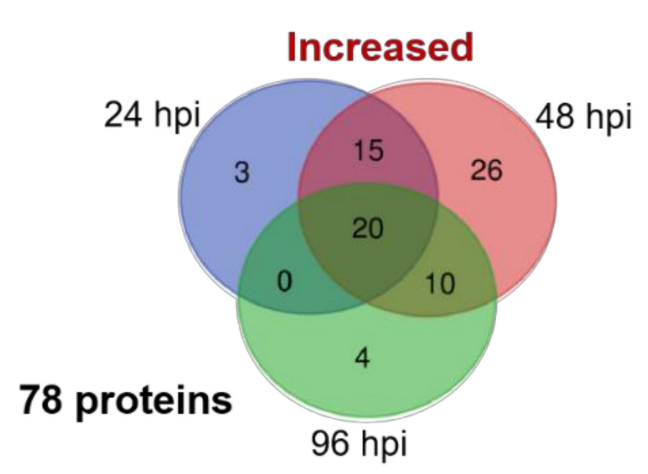

B
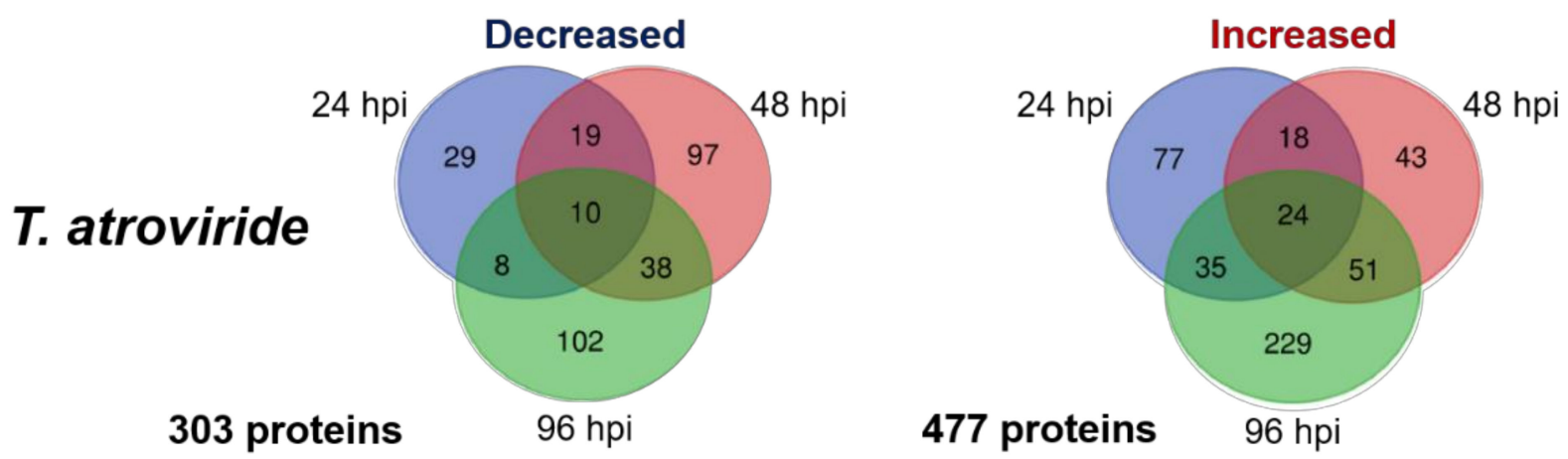

Figure 2. Venn diagrams showing the distribution of decreased and increased proteins at 24, 48, and $96 \mathrm{~h}$ of interaction. (A) Arabidopsis secretome. (B) T. atroviride secretome. Venn diagrams were constructed using the BEG tool (http:// bioinformatics.psb.ugent.be/webtools/Venn/, accessed on 2 August 2020). The total number of differentially expressed proteins is depicted to the left and belove of each diagram.

\begin{abstract}
2.2. Arabidopsis and T. atroviride Proteins Are Conventionally and Unconventionally Secreted during their Symbiosis

The differentially modulated secreted proteins of Arabidopsis and T. atroviride were categorized based on their predicted secretion pathways. We found that 84 proteins $(71 \%)$ of Arabidopsis and $314(40 \%)$ of T. atroviride were predicted to be conventionally secreted. In addition, 30 proteins $(25.5 \%)$ of the plant and $331(43 \%)$ of the fungus were predicted as secreted by unconventional pathways. The remaining four proteins (3.5\%) of Arabidopsis and $135(17 \%)$ of T. atroviride were predicted as not secreted (Figure 3A, Figure 4A, and Table S2).
\end{abstract}




\section{A}

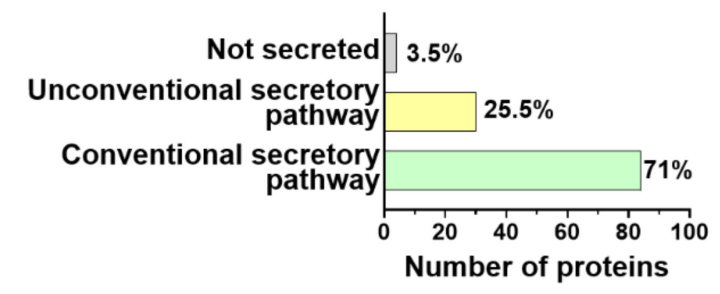

B

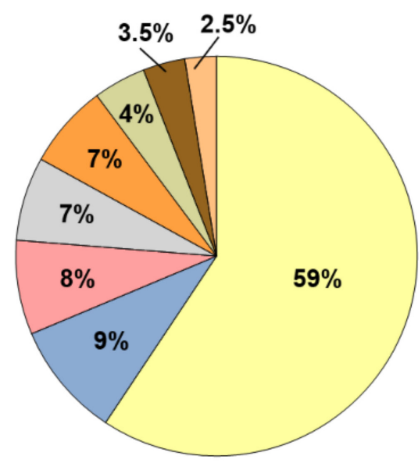

\section{Cellular component}

$\square$ Extracellular regio

Cytoplasm

$\square$ Plasma membrane

$\square$ Chloroplast

Secretory vesicle

Apoplast

Others

$\square$ Cell wall
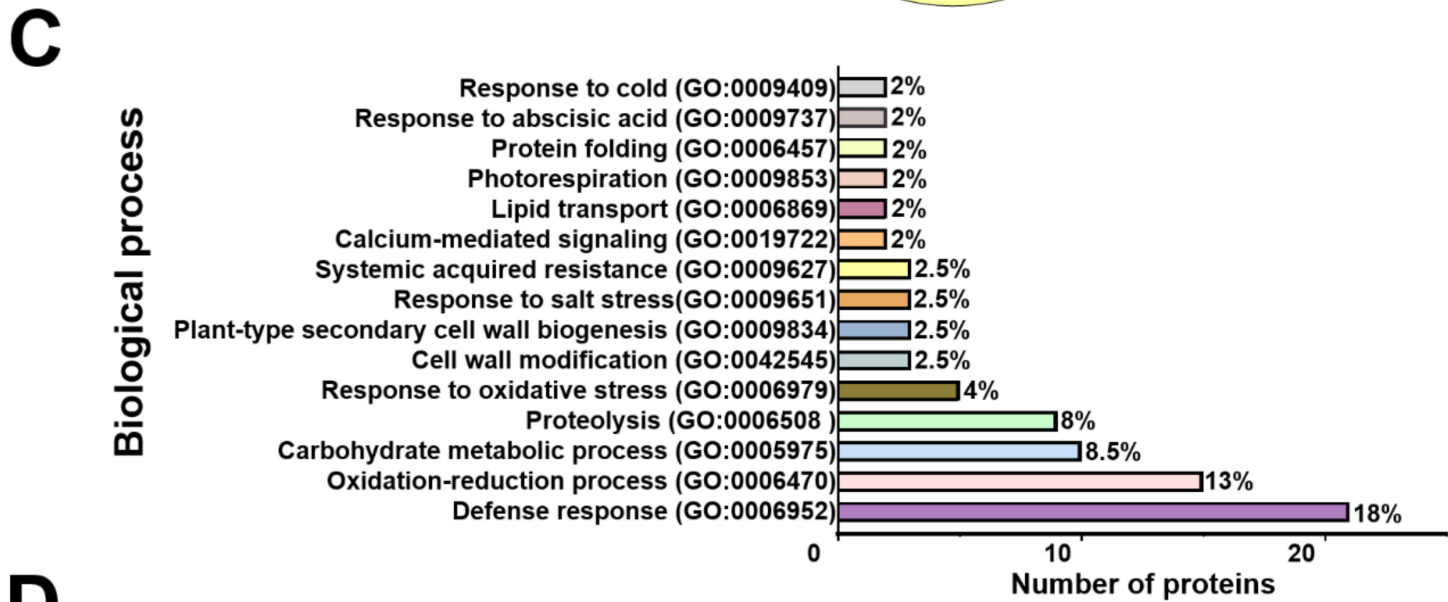

D

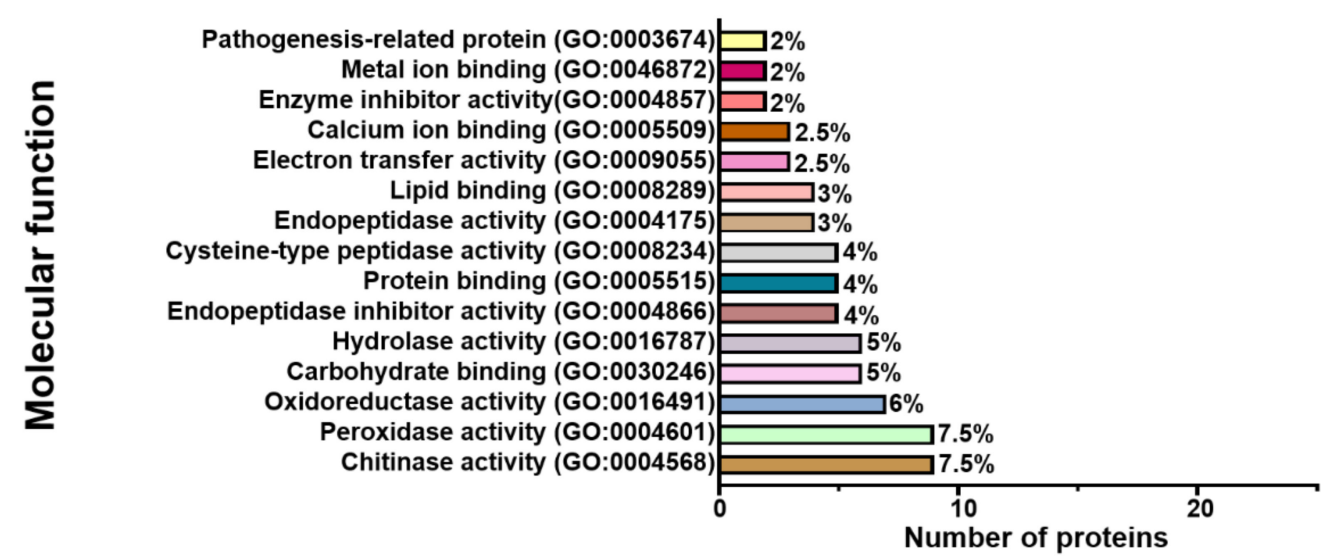

Figure 3. Prediction of putative secretion pathways and functional annotation of Arabidopsis secreted proteins. (A) Prediction of secretion pathways for Arabidopsis proteins during its interaction with T. atroviride. (B) Pie chart for the cellular component of Arabidopsis secreted proteins. Others include the vacuole, endoplasmic reticulum, and nucleus predicted. (C) Horizontal bar graphic for the top 15 biological processes of Arabidopsis secreted proteins predicted. Bars represent the number of proteins implied in a specific biological process. (D) Horizontal bar graphic for the top 15 molecular functions predicted. Prediction of secretion pathways was performed using SECRETOOL [29], SecretomeP v2.0 [30], and OutCyte v1.0 [31]. Functional annotation was performed with Gene Ontology (GO) terms using the Blast2GO software [32]. 
A

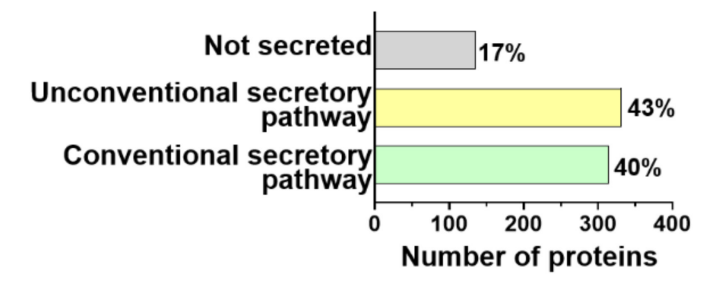

B

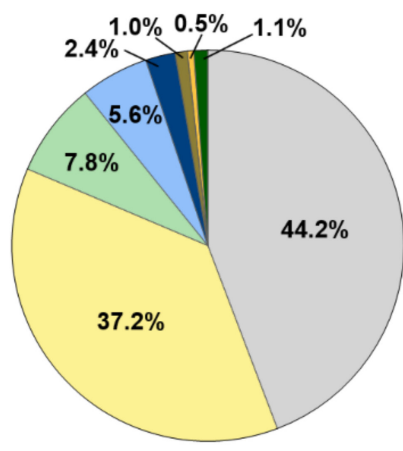

\section{Cellular component}

$\square$ Unknown
$\square$ Extracellular region
$\square$ Integral component
of membrane
$\square$ Cytoplasm
$\square$ Mitochondrion
Nucleus
$\square$ Ribosome
$\square$ Others
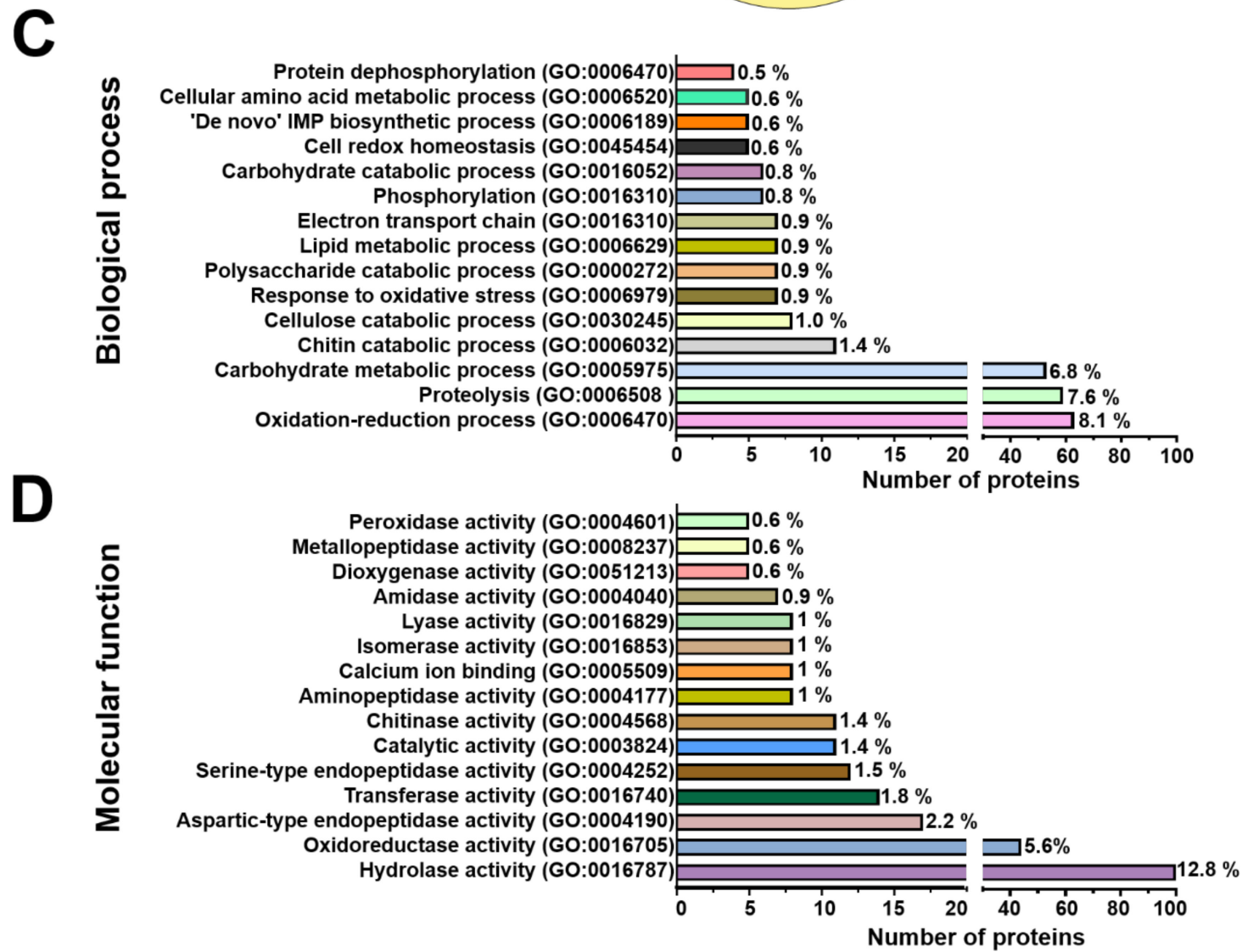

Figure 4. Prediction of putative secretion pathways and functional annotation of T. atroviride secreted proteins. (A) Prediction of secretion pathways of T. atroviride proteins during its interaction with Arabidopsis. (B) Pie chart for the cellular component of T. atroviride secreted proteins predicted by Blast2GO. Others included peroxisome, endosome, multivesicular body, cytoplasmic stress granule, cytoplasmic vesicle membrane, endoplasmic reticulum, and eukaryotic translation initiation factor 3 complex. (C) Horizontal bar graphic for the top 15 biological processes of T. atroviride-secreted proteins predicted by Blast2GO. Bars represent the number of proteins implied in a specific biological process. (D) Horizontal bar graphic for the top 15 molecular functions predicted by Blast2GO. The prediction of secretion pathways was performed using SECRETOOL [29], SecretomeP v2.0 [30], and the OutCyte v1.0 [31]. Functional annotation was performed with Gene Ontology (GO) terms using Blast2GO software [32].

\subsection{Functional Annotation of Arabidopsis and T. atroviride Secreted Proteins}

To better understand the diverse repertoire of Arabidopsis and T. atroviride-secreted proteins, a Gene Ontology (GO) analysis was performed, including cellular component, biological process, and molecular function terms (Table S2). Prediction of cellular localization for all plant modulated proteins pointed mainly to the extracellular region, plasma membrane, and cytoplasm. Proteins derived from secretory vesicles and the apoplast were 
also detected in the Arabidopsis secretome (Figure 3B). The most representative cellular components for T. atroviride-secreted proteins were the extracellular region, plasma membrane and cytoplasm. A small subset of T. atroviride proteins was predicted to localize in other cellular components, such as the endoplasmic reticulum, multivesicular body, and nucleus (Figure 4B). According to this analysis, Arabidopsis and T. atroviride secretomes were enriched mainly with extracellular proteins; however, a small subset of proteins probably derived from the plasma membrane and intracellular origin (Figures $3 \mathrm{~B}$ and $4 \mathrm{~B}$ ).

In Arabidopsis, the differentially modulated proteins were mainly classified in biological processes with potential functions related to defense response, oxidation-reduction, proteolysis, and response to oxidative stress processes (Figure 3C). For the molecular function term, proteins were predicted to have chitinase, peroxidase, oxidoreductase, and hydrolase activities, among others (Figure 3D). No biological process was predicted for 13 proteins, nor was a molecular function predicted for 16 proteins of Arabidopsis (Table S2). Regarding the biological process term, T. atroviride proteins were mainly classified in oxidation-reduction, proteolysis, carbohydrate metabolism, chitin catabolism, and cellulose catabolism (Figure 4C). For the molecular function term, the T. atroviride secretome was enriched with proteins related to hydrolase, oxidoreductase, aspartic-type endopeptidase activities, as well as transferase activity, among others (Figure 4D).

\subsection{T. atroviride and Arabidopsis Secretomes Were Enriched with a Plethora of Enzymes}

Furthermore, the enzymatic functions of Arabidopsis and T. atroviride proteins were predicted and classified. According to this analysis, 539 proteins $(69 \%)$ of T. atroviride and 58 (49\%) of Arabidopsis were classified as enzymes (Table S2). As shown in Figure 5, the main sub-subclasses of enzymes modulated at the different times in the T. atroviride secretome were putative glycosidases, carboxylic ester hydrolases, enzymes with $\mathrm{NAD}^{+}$ or $\mathrm{NADP}^{+}$as acceptor, hydro-lyases, and aspartic endopeptidases. Moreover, phosphoric monoester hydrolases and enzymes acting on linear amides were predicted at the three times of interaction (Figure 5A-C). Some sub-sub classes of enzymes were only modulated at a particular time point of interaction, such as enzymes acting on superoxide as an acceptor, which were exclusively identified at $24 \mathrm{~h}$ (Figure 6A), whereas transaminases were only found at $96 \mathrm{~h}$ (Figure 5C).

The most abundant enzymes in the Arabidopsis secretome at the three times of coculture included putative peroxidases, chitinases, and cathepsins. Pectinesterases and lactoylglutathione lyases were also differentially modulated at the three times of interaction (Figure 6A-C). Two $\alpha$-mannosidases and the enzyme GGAT1 were found only at $48 \mathrm{~h}$ (Figure 6B).

Sixty Arabidopsis proteins were predicted to lack enzymatic functions; therefore, they were classified into functional protein families (Table S2). According to this analysis, these proteins belong to diverse families, including thioredoxin, jacalin, fasciclin, plastocyanin, and probable lipid transfer, among others (Figure S2). Of the 241 proteins from T. atroviride predicted without an enzymatic function, 138 proteins were classified into functional families such as eukaryotic Sm-like (LSM), fungal hydrophobin, glucosyltransferase, and glycosyl hydrolase among others (Figure S3).

In T. atroviride, the glycosidase sub-subclass was over-represented by enzymes likely involved in the degradation of plant cell wall polysaccharides, such as cellulases, endo-1,4$\beta$-xylanases, xyloglucan-specific, endo- $\beta-1,4$-glucanases, cellulose $1,4-\beta$-cellobiosidases, mannan endo-1,6- $\alpha$-mannosidases, and $\beta$-glucosidases (Table 1 and Table S2). Furthermore, some carboxylic ester hydrolases with a potential role in cell wall degradation were identified, including a cutinase, an acetylxylan esterase, and a lysophospholipase. Conversely, other enzymes involved in the hydrolysis of plant polysaccharides decreased during the time-course of interaction, such as $\beta$-glucosidases, xylan 1,4- $\beta$-xylosidases, and $\alpha$-L-arabinofuranosides (Table 1 and Table S2). 


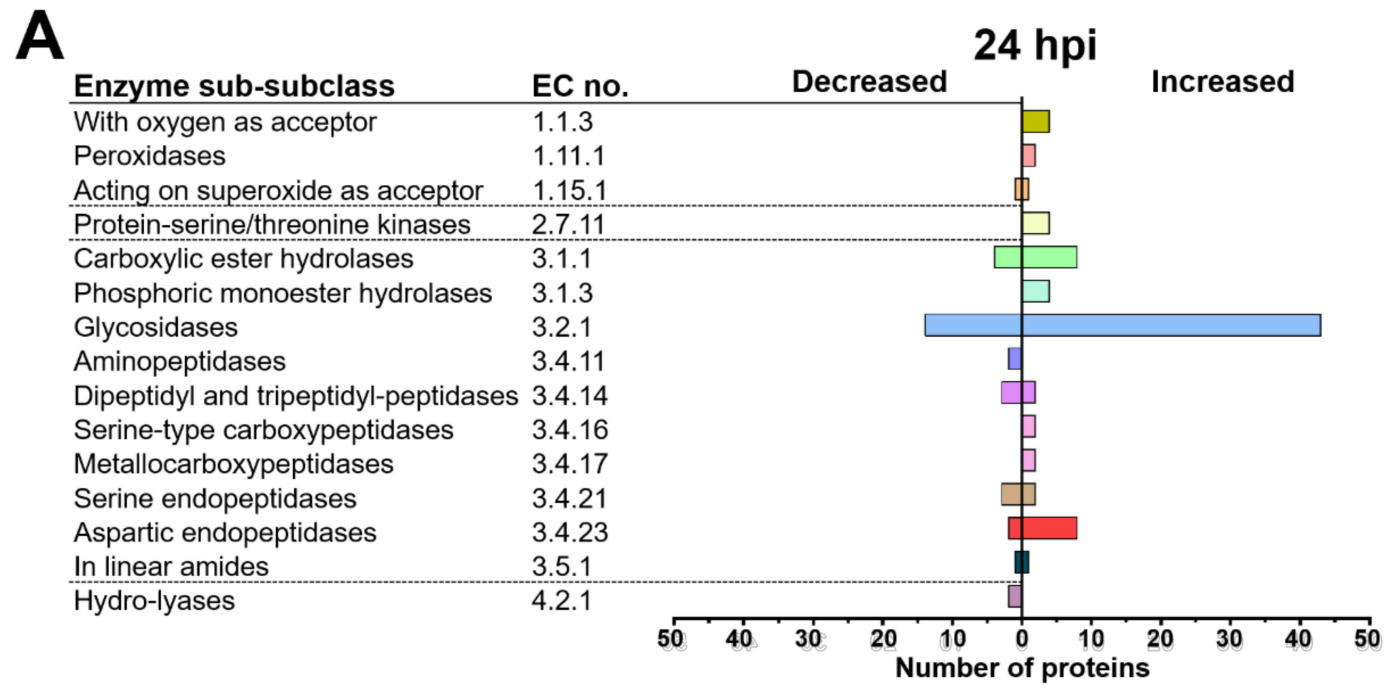

B

\begin{tabular}{lll} 
Enzyme sub-subclass & EC no. & Decreased \\
\hline With NAD+ $^{+}$or NADP+ as acceptor & 1.1 .1 &
\end{tabular}

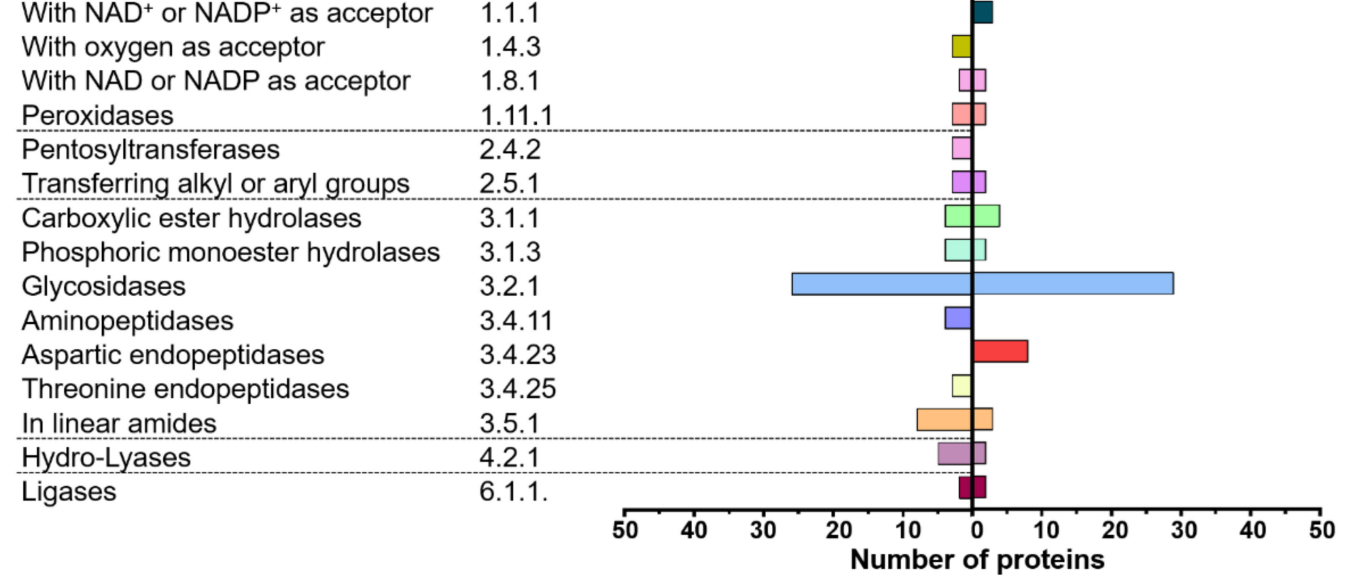

C.

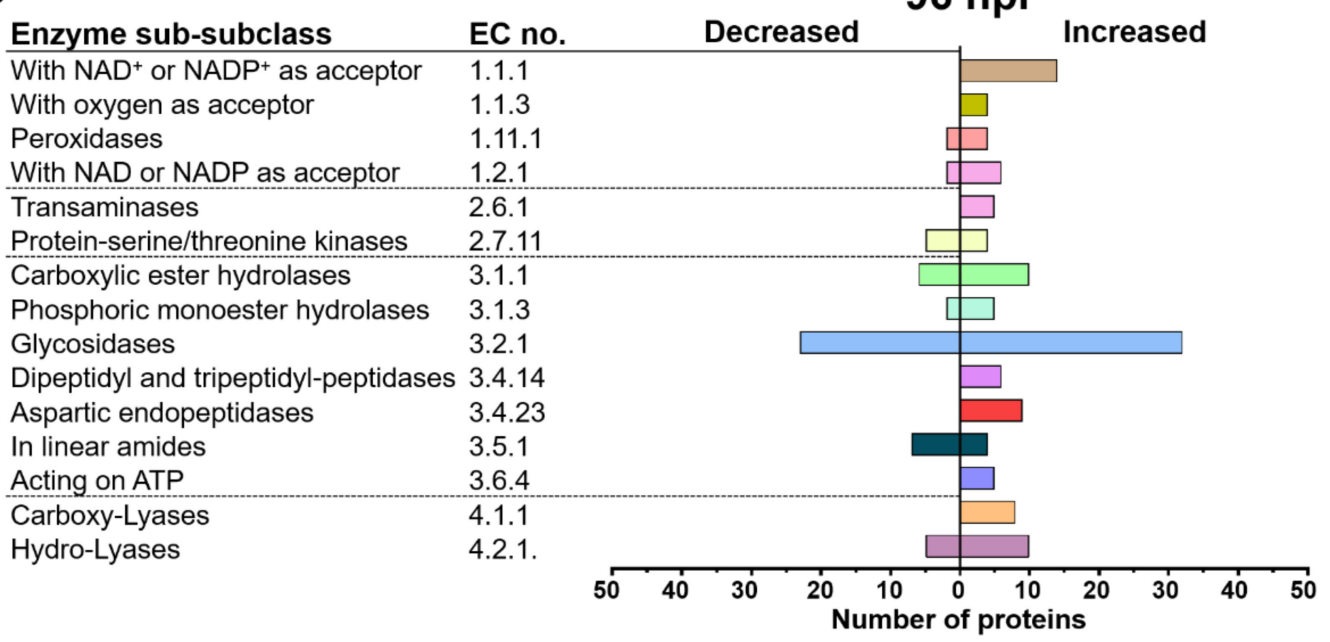

Figure 5. T. atroviride secreted mainly glycosidases and aspartic endopeptidases during its interaction with Arabidopsis. (A) Sub-subclasses of enzymes identified in the secretome of T. atroviride at $24 \mathrm{~h}$, (B) $48 \mathrm{~h}$, and (C) $96 \mathrm{~h}$ of interaction with Arabidopsis. The classification was based on the enzyme activity prediction using BRENDA [33]. 
A

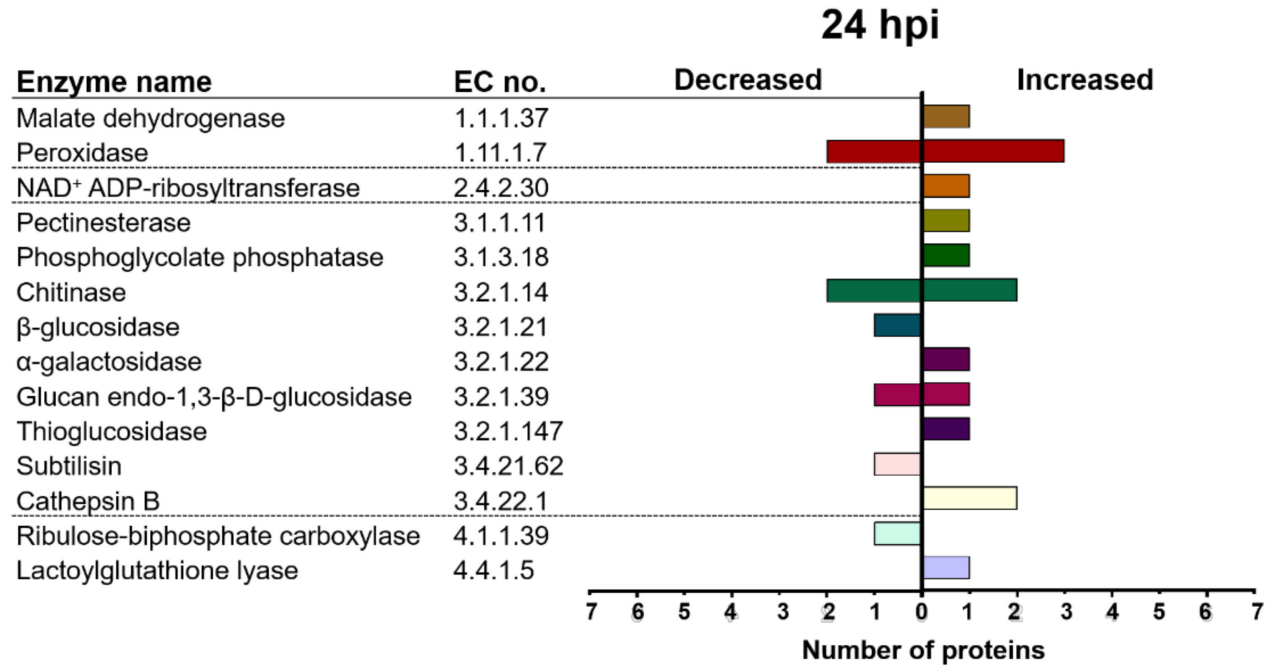

B

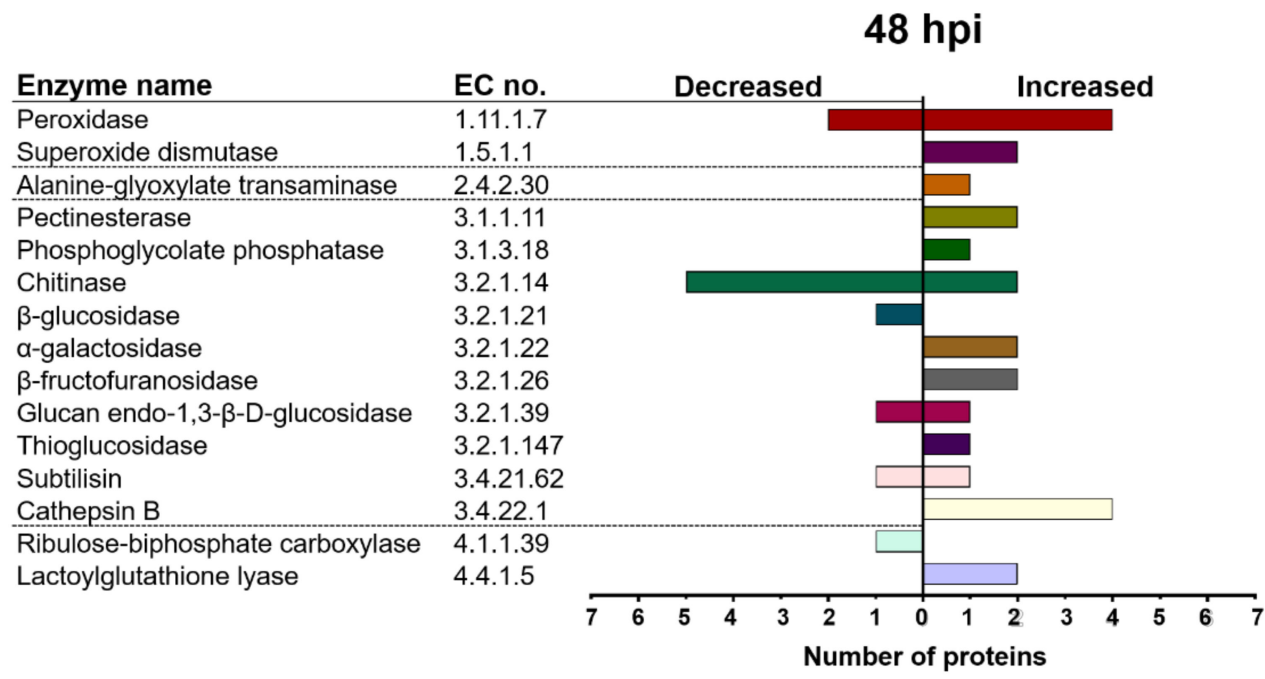

C

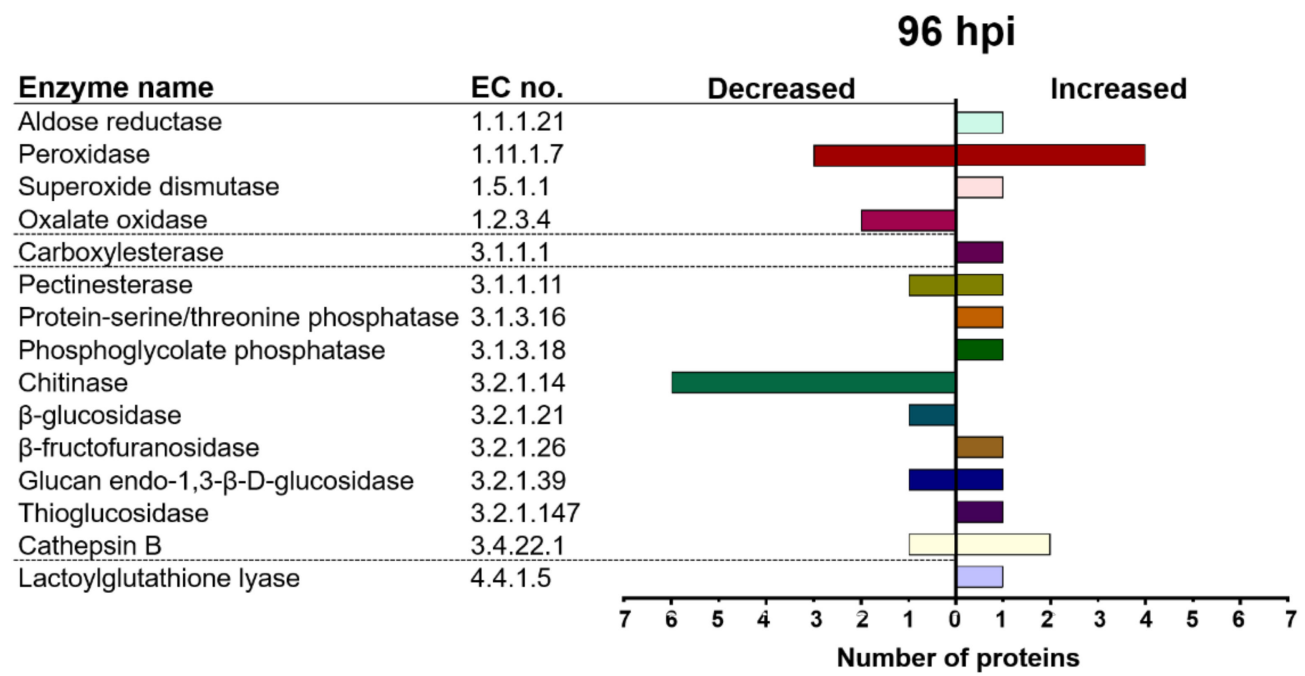

Figure 6. Arabidopsis responded to the presence of T. atroviride secreting mainly peroxidases and cathepsins B. (A) Enzymes identified in the Arabidopsis's secretome at $24 \mathrm{~h},(\mathrm{~B}) 48 \mathrm{~h}$, and (C) $96 \mathrm{~h}$ of interaction with T. atroviride. The classification was based on the enzyme activity prediction using BRENDA [33]. 
Table 1. Representative predicted enzymes differentially modulated in T. atroviride secretome at 24,48 , and $96 \mathrm{~h}$ of co-culture with Arabidopsis.

\begin{tabular}{|c|c|c|c|c|c|c|}
\hline JGI Id * & Enzyme Name ${ }^{* *}$ & EC No. ** & $\begin{array}{l}\text { Confidence } \\
\text { Score }\end{array}$ & \multicolumn{3}{|c|}{$\begin{array}{l}\text { Fold Change } * * * \\
\text { (Log2 Mean) }\end{array}$} \\
\hline \multicolumn{3}{|c|}{ Response to oxidative stress } & & $24 \mathrm{~h}$ & $48 \mathrm{~h}$ & $96 \mathrm{~h}$ \\
\hline 300451 & Peroxidase & EC 1.11.1.17 & 0.72 & 9.1 & 1.9 & 1.1 \\
\hline 88379 & Catalase-peroxidase & EC 1.11.1.21 & 1.7 & 2.1 & -1.0 & 0.5 \\
\hline 300992 & $\begin{array}{l}\text { Thioredoxin- } \\
\text { dependent } \\
\text { peroxiredoxin }\end{array}$ & EC 1.11.1.24 & 1.57 & 0 & 3.4 & 6.9 \\
\hline 297668 & Catalase & EC 1.11.1.6 & 2.5 & 0 & -4.9 & 10.8 \\
\hline 94401 & $\begin{array}{l}\text { Glutathione } \\
\text { peroxidase }\end{array}$ & EC 1.11.1.9 & 0.76 & 0 & 3.3 & 0.2 \\
\hline 215831 & $\begin{array}{l}\text { Superoxide } \\
\text { dismutase }\end{array}$ & EC 1.15.1.1 & 0.76 & 4.7 & 1.0 & 0.4 \\
\hline 299895 & $\begin{array}{l}\text { Cytochrome-c } \\
\text { peroxidase }\end{array}$ & EC 1.11.1.5 & 0.94 & 0 & -2.9 & -2.9 \\
\hline 155960 & Catalase-peroxidase & EC 1.11.1.21 & 1.7 & 3.7 & -6.5 & 0.2 \\
\hline 298583 & $\begin{array}{l}\text { Superoxide } \\
\text { dismutase }\end{array}$ & EC 1.15.1.1 & 2.57 & 0 & -2.5 & -2.2 \\
\hline \multicolumn{7}{|c|}{ Cell-wall degrading enzymes } \\
\hline 84753 & Acetylxylan esterase & EC 3.1.1.72 & 0.94 & 6.2 & 3.8 & 2.4 \\
\hline 297844 & Cutinase & EC 3.1.1.74 & 0.72 & 5.9 & 5.9 & 4.0 \\
\hline 296657 & $\begin{array}{l}\text { Mannan endo-1,6- } \alpha- \\
\text { mannosidase }\end{array}$ & EC 3.2.1.101 & 1.62 & 5.6 & 2.9 & 4.0 \\
\hline 44429 & $\begin{array}{c}\text { Xyloglucan-specific } \\
\text { endo- } \beta-1,4- \\
\text { glucanase }\end{array}$ & EC 3.2.1.151 & 0.81 & 4.9 & 2.8 & 4.5 \\
\hline 314392 & Cellulase & EC 3.2.1.4 & 0.94 & 4.4 & 7.2 & 10.1 \\
\hline 221999 & Cellulase & EC 3.2.1.4 & 0.94 & 3.1 & 4.7 & 5.1 \\
\hline 88310 & Endo-1,4- $\beta$-xylanase & EC 3.2.1.8 & 0.72 & 2.4 & 9.3 & 3.7 \\
\hline 44894 & $\begin{array}{c}\text { Cellulose } \\
1,4-\beta \text {-cellobiosidase }\end{array}$ & EC 3.2.1.91 & 1.89 & 4.2 & 5.4 & 5.0 \\
\hline 88458 & $\begin{array}{c}\text { Cellulose } \\
1,4-\beta \text {-cellobiosidase }\end{array}$ & EC 3.2.1.91 & 1.89 & 4.1 & 5.4 & 6.9 \\
\hline 91075 & $\begin{array}{c}\text { Glucan } \\
1,3-\beta \text {-glucosidase }\end{array}$ & EC 3.2.1.58 & 0.76 & 4.8 & 2.3 & 0 \\
\hline 139054 & $\beta$-glucosidase & EC 3.2.1.21 & 0.94 & 4.7 & 5.6 & 10.4 \\
\hline 42986 & $\beta$-glucosidase & EC 3.2.1.21 & 1.7 & -4.8 & -5.9 & -3.8 \\
\hline 223991 & $\beta$-glucosidase & EC 3.2.1.21 & 0.94 & -6.5 & -2.2 & -2.9 \\
\hline 302027 & $\beta$-glucosidase & EC 3.2.1.21 & 0.94 & -8.2 & -6.6 & -0.9 \\
\hline 161158 & $\begin{array}{c}\text { Xylan } \\
1,4-\beta \text {-xylosidase }\end{array}$ & EC 3.2.1.37 & 0.94 & -2.3 & -2.3 & -1.6 \\
\hline 161159 & $\begin{array}{c}\text { Xylan } \\
1,4-\beta \text {-xylosidase }\end{array}$ & EC 3.2.1.37 & 0.94 & -4.0 & -4.9 & -0.9 \\
\hline \multicolumn{7}{|c|}{ Proteolysis } \\
\hline 90832 & Pepsin A & EC 3.4.23.1 & 0.76 & 6.4 & 3.4 & 0 \\
\hline 142040 & Aspergillopepsin I & EC 3.4.23.18 & 1.81 & 2.4 & 3.9 & 0.2 \\
\hline 298116 & Aspergillopepsin II & EC 3.4.23.19 & 0.76 & 3.9 & 3.4 & 0 \\
\hline 137451 & Penicillopepsin & EC 3.4.23.20 & 0.81 & 2.6 & 6.1 & 9.2 \\
\hline 131866 & Penicillopepsin & EC 3.4.23.20 & 0.86 & 1.5 & 3.8 & 5.2 \\
\hline 33651 & Rhizopuspepsin & EC 3.4.23.21 & 0.76 & 0.6 & 3.1 & 6.2 \\
\hline 176535 & Candidapepsin & EC 3.4.23.24 & 0.76 & 3.8 & 3.5 & 0 \\
\hline 28954 & Candidapepsin & EC 3.4.23.24 & 0.76 & 2.5 & 0.1 & 13.0 \\
\hline 292296 & Candidapepsin & EC 3.4.23.24 & 0.76 & 2.2 & 0.4 & 7.5 \\
\hline 34007 & Candidapepsin & EC 3.4.23.24 & 0.76 & 1.6 & 0.4 & 9.2 \\
\hline
\end{tabular}


Table 1. Cont.

\begin{tabular}{|c|c|c|c|c|c|c|}
\hline JGI Id * & Enzyme Name ${ }^{* *}$ & EC No. ** & $\begin{array}{l}\text { Confidence } \\
\text { Score }{ }^{* *}\end{array}$ & \multicolumn{3}{|c|}{$\begin{array}{l}\text { Fold Change }{ }^{* * *} \\
\text { (Log2 Mean) }\end{array}$} \\
\hline 220221 & $\begin{array}{l}\text { Tripeptidyl- } \\
\text { peptidase } \\
\text { II }\end{array}$ & EC 3.4.14.10 & 0.94 & -5.4 & -4.4 & 0 \\
\hline 36337 & Deuterolysin & EC 3.4.24.39 & 1.7 & 0 & -1.4 & -8.4 \\
\hline 40863 & Aspergillopepsin I & EC 3.4.23.18 & 0.81 & -2.1 & -2.7 & 0 \\
\hline 54917 & $\begin{array}{l}\text { Dipeptidyl- } \\
\text { peptidase } \\
\text { II }\end{array}$ & EC 3.4.14.2 & 0.72 & -3.0 & -0.1 & 0 \\
\hline 321810 & C5a peptidase & EC 3.4.21.110 & 0.76 & -3.5 & 0 & -10.5 \\
\hline \multicolumn{7}{|c|}{ Dephosphorylation } \\
\hline 215617 & 3-phytase & EC 3.1.3.8 & 0.76 & 4.7 & 0 & 0.8 \\
\hline 44629 & Acid phosphatase & EC 3.1.3.2 & 1.7 & 2.0 & -1.2 & 0.6 \\
\hline 298464 & $\begin{array}{l}\text { Inositol-phosphate } \\
\text { phosphatase }\end{array}$ & EC 3.1.3.25 & 1.62 & 0 & 4.3 & 7.1 \\
\hline 298832 & 5'-nucleotidase & EC 3.1.3.5 & 0.94 & -1.4 & 0.9 & 4.3 \\
\hline 89336 & $\begin{array}{c}\text { Protein- } \\
\text { serine/threonine } \\
\text { phosphatase }\end{array}$ & EC 3.1.3.16 & 1.7 & 3.0 & 0.9 & 3.9 \\
\hline 147790 & $\begin{array}{c}\text { Phosphoglycolate } \\
\text { phosphatase }\end{array}$ & EC 3.1.3.18 & 0.81 & 0 & 0 & 4.5 \\
\hline
\end{tabular}

* JGI id numbers were exported from DOE Joint Genome Institute (https:/ /mycocosm.jgi.doe.gov/Triat2/Triat2.home.html, accessed on 19 October 2020). ** According to the analysis of the corresponding protein, the enzyme names, the EC numbers, and confidence scores were extracted from BRENDA database [33]. *** Fold change indicates increased (orange color) or decreased (blue color) T. atroviride proteins in co-culture with Arabidopsis at 24, 48, and 96 compared with T. atroviride growing alone (control).

Additionally, in the T. atroviride secretome, a group of antioxidant enzymes involved in ROS detoxification was significantly increased in response to the plant, such as those acting on a peroxide as acceptor. Some of these were exclusively increased at $24 \mathrm{~h}$ of interaction (Table 1 and Table S2).

Furthermore, in the T. atroviride secretome, phosphoric monoester hydrolases that participate in protein dephosphorylation and nucleotide catabolic processes were increased by the presence of the plant, including a putative 2-phosphoglycolate phosphatase, an acid phosphatase, and a 3-phytase, among others (Table 1 and Table S2).

Among the peptidases modulated at different times in the T. atroviride secretome, the aspartic endopeptidases were the most over-represented (Figure 5A-C). Serine-type carboxypeptidases and a metallocarboxypeptidase were accumulated mainly at $24 \mathrm{~h}$ of co-culture (Figure 5A), whereas at $96 \mathrm{~h}$, an accumulation of several dipeptidyl/tripeptidyl peptidases was observed (Figure 5C and Table S2).

A group of enzymes involved in oxidative stress response was prominent among the increased subsets of Arabidopsis proteins, including the thioredoxins (TRXs) BAS1A, TRXH3, TRX5, TRXM1, and ATHM2 (Table S2). Other enzymes with a known role in oxidative stress response comprise two superoxide dismutases, SODC2 and FSD1 (Fe superoxide dismutase 1) (Table S2). Furthermore, eight class III peroxidases (PER3, PER22, PER32, PER34, PER39, PER52, PER69, and PER71) were differentially accumulated in the Arabidopsis secretome (Table 2 and Table S2). 
Table 2. Representative predicted enzymes differentially modulated in Arabidopsis secretome at 24, 48, and 96 of co-culture with T. atroviride.

\begin{tabular}{|c|c|c|c|c|c|c|c|}
\hline Locus_Tag * & $\begin{array}{c}\text { Gene } \\
\text { Symbol * }\end{array}$ & Enzyme Name ** & EC. No. ${ }^{* *}$ & $\begin{array}{l}\text { Confidence } \\
\text { Score }\end{array}$ & \multicolumn{3}{|c|}{$\begin{array}{l}\text { Fold Change } * * * \\
\text { (Log2 Mean) }\end{array}$} \\
\hline \multicolumn{3}{|c|}{ Response to oxidative stress } & & & $24 \mathrm{~h}$ & $48 \mathrm{~h}$ & $96 \mathrm{~h}$ \\
\hline At3g49120 & PER34 & Peroxidase & EC 1.11.1.17 & 2.70 & 6.0 & 6.8 & 3.1 \\
\hline At2g38380 & PER22 & Peroxidase & EC 1.11.1.17 & 2.70 & 2.2 & 8.2 & 7.6 \\
\hline At1g05260 & PER3 & Peroxidase & EC 1.11.1.17 & 2.70 & 2.0 & 8.2 & 4.4 \\
\hline At4g11290 & PER39 & Peroxidase & EC 1.11.1.17 & 2.70 & 0 & 2.6 & 0 \\
\hline At3g32980 & PER32 & Peroxidase & EC 1.11.1.17 & 2.70 & 0 & -1.8 & 3.8 \\
\hline At3g11630 & BAS1A & $\begin{array}{l}\text { Thioredoxin-dependent } \\
\text { peroxiredoxin }\end{array}$ & EC 1.11.1.24 & 3.70 & 1.9 & 3.0 & 0 \\
\hline At2g28190 & SODC & Superoxide dismutase & EC 1.15.1.1 & 3.70 & 0 & 2.7 & 0 \\
\hline At4g25100 & FDSD1 & Superoxide dismutase & EC 1.15.1.1 & 2.65 & 0 & 4.3 & 3.7 \\
\hline At5g05340 & PER52 & Peroxidase & EC 1.11.1.17 & 2.70 & -1.6 & -2.8 & -2.8 \\
\hline At5g64120 & PER71 & Peroxidase & EC 1.11.1.17 & 2.70 & -2.3 & -4.5 & -7.0 \\
\hline At5g64100 & PER69 & Peroxidase & EC 1.11.1.17 & 2.70 & -3.0 & -1.6 & -6.7 \\
\hline \multicolumn{8}{|c|}{ Defense response } \\
\hline At4g01610 & CATB3 & Cathepsin B & EC 3.4.22.1 & 1.74 & 0 & 3.9 & 0 \\
\hline At3g19390 & RD21C & Cathepsin B & EC 3.4.22.1 & 1.82 & 0 & 6.6 & 3.4 \\
\hline At5g60360 & ALP & Cathepsin B & EC 3.4.22.1 & 0.94 & 3.6 & 8.7 & 6.2 \\
\hline At5g43060 & RD21B & Cathepsin B & EC 3.4.22.1 & 1.82 & 5.8 & 0.1 & 1.6 \\
\hline At1g 47128 & RD21A & Cathepsin B & EC 3.4.22.1 & 1.82 & 0.2 & 5.6 & -2.1 \\
\hline At1g03220 & F15K9.17 & Chitinase & EC 3.2.1.14 & 0.81 & 0 & 2.5 & 1.9 \\
\hline At4g16260 & At4g16260 & $\begin{array}{l}\text { Glucan endo- } 1,3-\beta-\mathrm{D}- \\
\text { glucosidase }\end{array}$ & EC 3.2.1.39 & 1.89 & 4.8 & 8.4 & 2.6 \\
\hline At4g19810 & $\mathrm{CHIC}$ & Chitinase & EC 3.2.1.14 & 2.70 & 0 & -2.4 & -2.1 \\
\hline At2g43620 & CHI62 & Chitinase & EC 3.2.1.14 & 2.70 & 0 & -2.8 & -1.9 \\
\hline At2g43610 & CHI61 & Chitinase & EC 3.2.1.14 & 2.70 & -1.4 & -3.3 & -6.4 \\
\hline At2g43570 & $\mathrm{CHI}$ & Chitinase & EC 3.2.1.14 & 2.70 & -2.1 & -4.9 & -9.2 \\
\hline At3g54420 & $\mathrm{CH} 5$ & Chitinase & EC 3.2.1.14 & 2.70 & -2.7 & -5.8 & -7.8 \\
\hline At1g75040 & PR5 & $\begin{array}{l}\text { Glucan endo-1,3- } \beta \text {-D- } \\
\text { glucosidase }\end{array}$ & EC 3.2.1.39 & 0.86 & -5.5 & -6.8 & -7.9 \\
\hline \multicolumn{8}{|c|}{ Photorespiration } \\
\hline At5g36790 & PGP1B & $\begin{array}{c}\text { Phosphoglycolate } \\
\text { phosphatase }\end{array}$ & EC 3.1.3.18 & 2.70 & 3.9 & 6.3 & 4.4 \\
\hline At1g23310 & GGAT1 & $\begin{array}{l}\text { Glutamate:glyoxylate } \\
\text { aminotransferase } 1\end{array}$ & EC 2.6.1.4 & 2.70 & 0 & 3.5 & 0 \\
\hline AtCg00490 & RBCL & $\begin{array}{l}\text { Ribulose-bisphosphate } \\
\text { carboxylase }\end{array}$ & EC 4.1.1.39 & 3.70 & -3.5 & -2.4 & 0 \\
\hline
\end{tabular}

* Locus tags and gene symbols were extracted from The Arabidopsis Information Resources (TAIR) database https://www.arabidopsis.org/ (accessed on 21 September 2020). ** According to the analysis of the corresponding protein, the enzyme names, the EC numbers and confidence scores were extracted from BRENDA database [33]. *** Fold change indicates increased (orange color) or decreased (blue color) Arabidopsis proteins in co-culture with T. atroviride at 24, 48, and 96 compared with Arabidopsis growing alone (control).

A group of enzymes, which may be involved in plant defense, was increased in the plant secretome, including the hevein-like HEVL and the plant defensin PDF1.2. The decreased enzymes included the glucan endo-1,3- $\beta$-D-glucosidase PR5, PR1, and two defensin-like proteins (DF195 and DF206) (Table S2). In addition, nine putative chitinases were found, most of which were decreased mainly at 48 and $96 \mathrm{~h}$. Only the chitinase F15K9.17 increased in the presence of the fungus (Table 2 and Table S2).

The accumulation of the serine protease inhibitor UPI, the Kunitz trypsin inhibitor KTI1, and the Kunitz trypsin inhibitor KTI4, which are linked to plant defense, was observed in the Arabidopsis secretome. In contrast, the serine protease inhibitor (At2g38870) and the Kunitz trypsin inhibitor KTI5 were strongly decreased through all interaction times (Table S2). Other abundant proteins in the plant secretome were cysteine endopeptidases 
with a known role in plant defense, and several putative cathepsins (Table 2 and Table S2) of the papain family of cysteine proteases (Table S2). Other peptidases in the Arabidopsis secretome included a lysosomal Pro-Xaa carboxypeptidase and two subtilisin-like proteases (Table S2). Furthermore, our plant secretome data revealed an enrichment of enzymes with no known roles in symbiotic interactions, such as phosphoglycolate phosphatase, PGP1B, ribulose bisphosphate carboxylase, RBCL (large chain), and GGAT1, which are related to photorespiration (Table 2 and Table S2).

\subsection{GGAT1 Plays a Minor Role in Plant Growth Stimulation by T. atroviride}

As mentioned above, we found increased levels of GGAT1 in the plant secretome. It was reported that GGAT1 is secreted in Arabidopsis extracellular vesicles [28]. Abundance in the secretome decreased in response to the bacterial phytopathogen P. syringae (Supplementary Table S1, [28]), which indicates a potential role in plant-microbe interaction. However, its role in plant-pathogen or plant-beneficial microbe interaction has not been studied. Based on this information, we hypothesized that GGAT1 could be potentially involved in Arabidopsis-T. atroviride interaction. Thus, to test whether GGAT1 is required in Arabidopsis for plant growth stimulation by T. atroviride, the plant growth phenotypes and dry weights of Col-0 and ggat1-2 lines were determined. As shown in Figure 7A,B, no significant differences in plant growth phenotype between ggat1-2 and Col-0 control plants were observed. Both Col-0 and ggat1-2 plants treated with T. atroviride showed significantly enhanced growth at 21-post treatment compared with untreated seedlings. However, the plant growth stimulation of ggat1-2 by T. atroviride was significantly smaller $(p<0.05)$ than wild type Col-0 seedlings under the same conditions. This result indicated that GGAT1 is partially required for plant growth stimulation by the beneficial fungus.

2.6. GGAT1 Is Potentially Involved in the Negative Regulation of the Systemic Resistance against B. cinerea

Furthermore, we analyzed whether GGAT1 is required for the induction of plant systemic resistance by $T$. atroviride against $B$. cinerea. To this end, ggat1-2 plants previously treated or not with $T$. atroviride were infected with $B$. cinerea, and the leaves damage was evaluated. ggat1-2 seedlings untreated with T. atroviride exhibited decreased leaves damage compared to Col-0 untreated plants with T. atroviride (Figure 7C,D). ggat1-2 plants pretreated with $T$. atroviride and post infected with $B$. cinerea showed slightly more foliar damage area compared to Col-0 seedlings pretreated with the mutualistic fungus. The differences were statistically significant. These results suggest that GGAT1 participates in the negative regulation of the systemic resistance against $B$. cinerea and that this enzyme is partially required for the induction of plant systemic resistance by T. atroviride against the phytopathogen.

2.7. In Arabidopsis, GGAT1 Participates in the Resistance against B. cinerea, Tentatively through a Mechanism Involving $\mathrm{H}_{2} \mathrm{O}_{2}$ Production

Previously, it was reported that an insertional mutant allele of GGAT1 (ggt1-1) in Arabidopsis shows increased levels of hydrogen peroxide $\left(\mathrm{H}_{2} \mathrm{O}_{2}\right)$ in leaves [34]. Therefore, we hypothesized that in Arabidopsis, GGAT1 could be involved in the response to both T. atroviride and B. cinerea. To test whether ggat1-2 allele is affected in the production of $\mathrm{H}_{2} \mathrm{O}_{2}$, Col-0, and ggat1-2, leaves of control plants were stained with $3,3^{\prime}$-diaminobenzidine (DAB). Indeed, notable precipitates of DAB were visible in the leaves of ggat1-2 plants compared with Col-0 (Figure 8), whereas after $24 \mathrm{~h}$ of challenging against B. cinerea, DAB precipitates in ggat1-2 leaves were less visible than Col-0, indicating that the systemic production of $\mathrm{H}_{2} \mathrm{O}_{2}$ in ggat1-2 leaves is negatively affected upon B. cinerea attack (Figure 8). Furthermore, DAB staining revealed that T. atroviride triggered the accumulation of $\mathrm{H}_{2} \mathrm{O}_{2}$ in Col-0 leaves, whereas low precipitate of DAB was observed in leaves of ggat1-2 plants pretreated with T. atroviride (Figure 8). Moreover, ggat1-2 plants pretreated with T. atroviride and infected with $B$. cinerea showed low levels of $\mathrm{H}_{2} \mathrm{O}_{2}$ accumulation compared with Col-0 under the same conditions (Figure 8). 
A
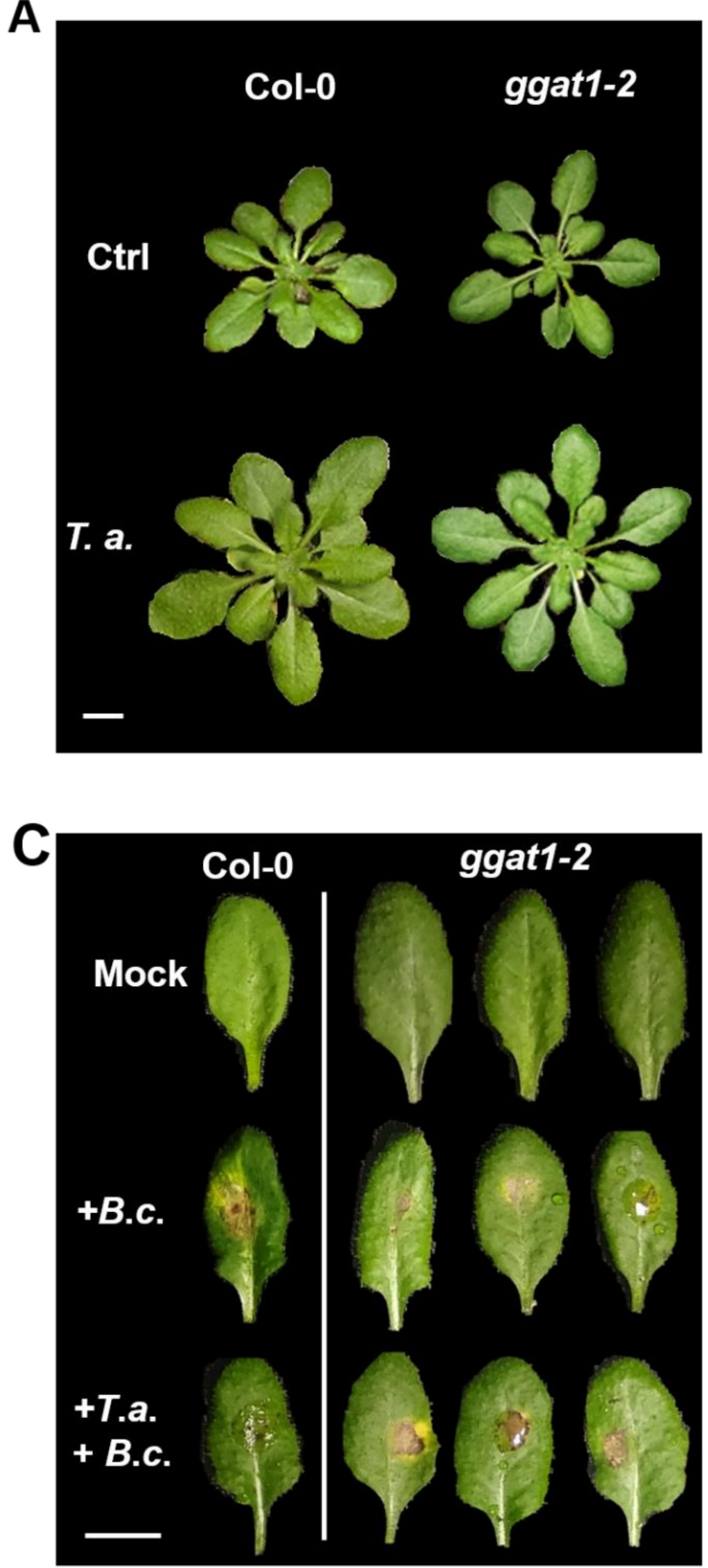

B

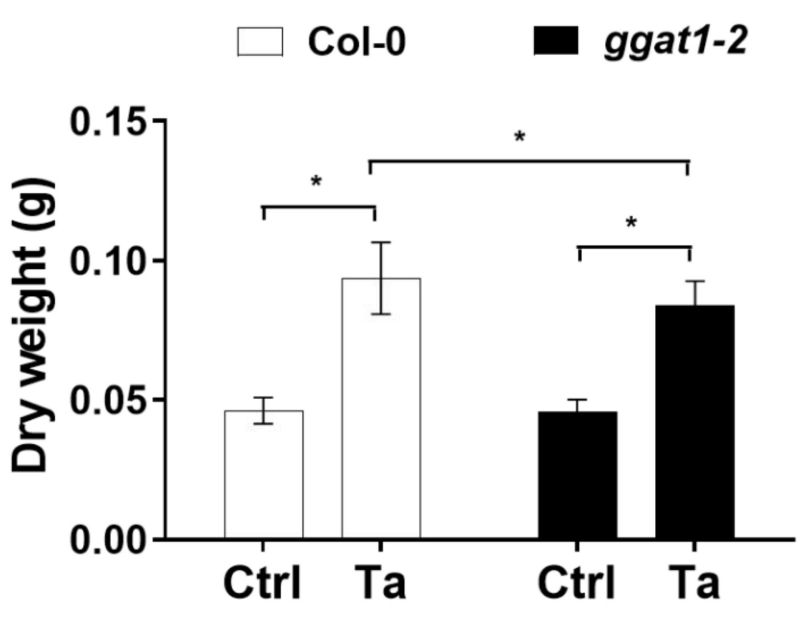

D

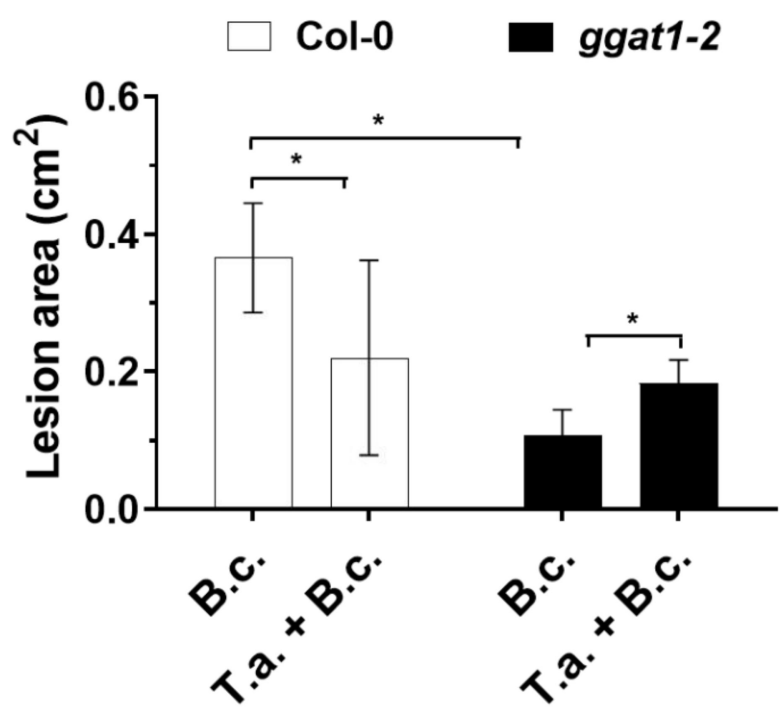

Figure 7. GGAT1 is partially required in Arabidopsis for plant growth induced by T. atroviride and potentially participates in the negative regulation of the systemic resistance against B. cinerea. Two-week-old Arabidopsis plants were root-pretreated with T. atroviride, whereas control plants were inoculated with buffer. (A) Plant phenotypes of growth response to T. atroviride. Pictures were taken at 18-days post-treatment. Scale bar, $1 \mathrm{~cm}$. (B) Dry weights of individual plants were determined at 21 days post-treatment. The experiments were repeated thrice with similar results. The data represent the means of 20 plants. Results were analyzed using a Tukey multiple comparison test $(\alpha=0.05)$. Asterisks indicate $p<0.05$. (C) Comparison of leaves damage between Col-0 and ggat1-2 seedlings inoculated with B. cinerea (+B. c). Plants treated with inoculation buffer were included as control (mock). Infections were carried out on three leaves from each plant previously treated or not with T. atroviride (18 days post-treatments, T. a. + B. c.). Pictures were taken at six days post infection. Scale bar, $1 \mathrm{~cm}$. (D) Lesion sizes ( $\left.\mathrm{cm}^{2}\right)$ of Arabidopsis leaves infected with B. cinerea were analyzed at six-days post infection (dpi) using ImageJ software. The experiments were repeated thrice with similar results. The data represent means of 24 leaves from a total of eight plants. Results were analyzed using a Tukey multiple comparison test $(\alpha=0.05)$. Asterisks indicate $p<0.05$. Error bars indicate SD. 
A

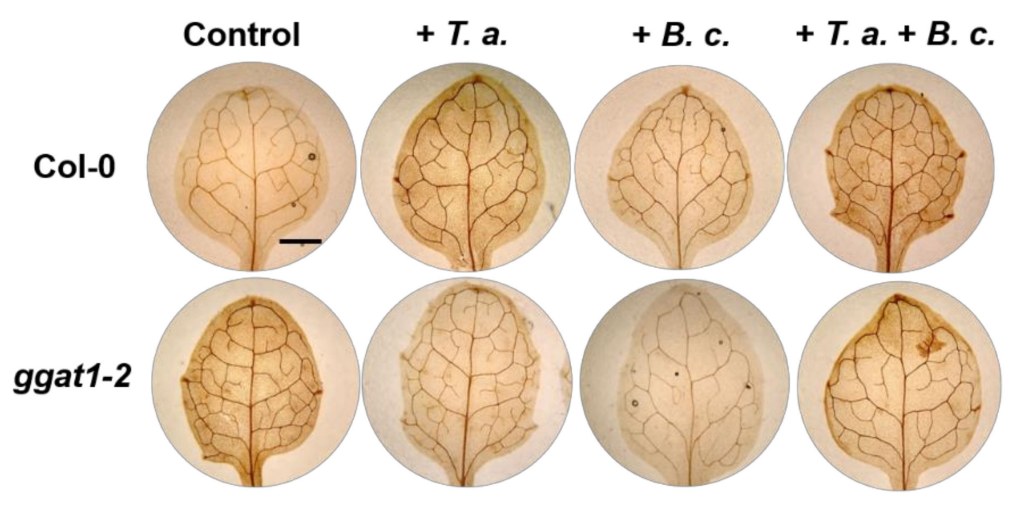

B

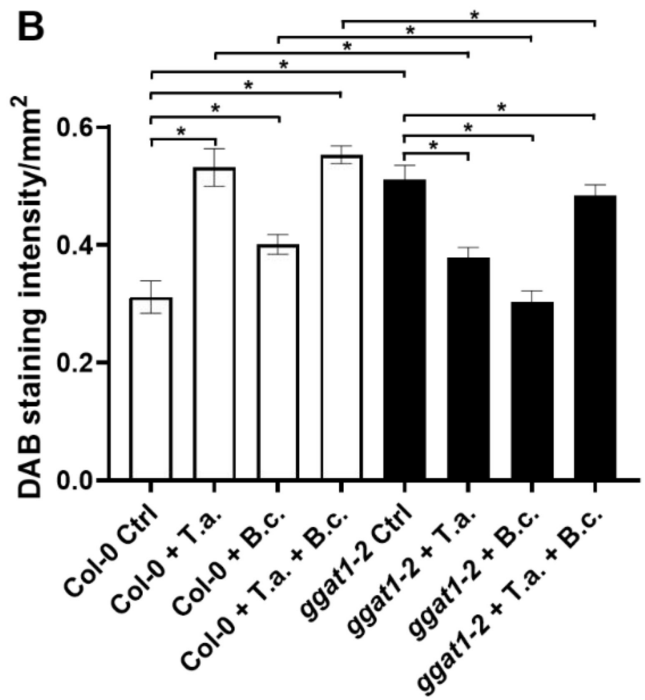

Figure 8. Histochemical detection of $\mathrm{H}_{2} \mathrm{O}_{2}$ in Arabidopsis leaves by DAB staining. (A) $\mathrm{H}_{2} \mathrm{O}_{2}$ in Arabidopsis leaves was visualized by DAB staining. Three leaves of each 12 -day-old Col-0 or ggat1-2 seedlings were inoculated with $B$. cinerea or with inoculation buffer as controls from plants previously treated $(+$ T. a. + B. c.) or not with T. atroviride $(+B$. c.). The histochemical detection of $\mathrm{H}_{2} \mathrm{O}_{2}$ in uninoculated leaves was evaluated one-day post-inoculation with the phytopathogen. Leaves infiltrated with buffer were included as controls (not shown). Pictures were taken at $4 \mathrm{x}$ magnification in a microscope (ZEISS Primostar). Representative leaves from 10 plants are shown. The experiments were repeated twice with similar results. Scale bar, $1 \mathrm{~mm}$. (B) DAB staining intensity as determined with Fiji, an image processing package distributed by ImageJ software (https:/ /imagej.net/Fiji, accessed on 29 May 2021). The data represent the means of 10 leaves from each condition. Results were analyzed using a Tukey multiple comparison test $(\alpha=0$. 05). Asterisk indicates $p<0.05$. Error bars indicate SD.

\section{Discussion}

\subsection{Arabidopsis and T. atroviride Secreted a Diverse Array of Proteins during Their Interaction}

The proteins secreted by the host plant and its fungal partner may play key roles in the establishment of a beneficial relationship. In this work, we identified a total of 126 secreted proteins of Arabidopsis and 1027 of T. atroviride over a time course in a semi-hydroponic system. In a previous study [26], it was reported that a total of 43 proteins of T. virens and 95 of maize are secreted during their interaction under hydroponic conditions. Here, we show that seven out of 97 proteins of maize overlapped with their orthologues in Arabidopsis. These included the PVR3-like protein, the chitinase B1 (COP451_MAIZE), the peroxidase PER67 (A0A1D6QGI0_MAIZE), the Barwin superfamily protein WIN1 (B6SH12_MAIZE), the endochitinase A (B4FTS6_MAIZE), the osmotin-like protein OSM34 (A0A1D6GKZ3_MAIZE), and a lactoylgluthatione lyase (COPK05_MAIZE). It was also reported that Arabidopsis secretes three endochitinases (At2g43570, At2g43620, and At3g12500) and the osmotin-like protein OSM34 (At4g11650) in response to the mutualistic fungus Piriformospora indica [35]. These findings suggest that Arabidopsis and maize plants respond to beneficial fungi by secreting a common array of enzymes related to plant defense. Moreover, a total of 280 secreted proteins of $T$. virens growing alone or in co-culture with maize in a hydroponic system were identified [27]. The comparison of our dataset with that reported by [27] showed that 159 proteins of T. atroviride overlapped with their orthologous proteins in T. virens; most of such proteins were glycosidases and peptidases. It is tempting to speculate that glycosidases of Trichoderma spp. could be playing a role in plant-Trichoderma interaction. In support of this, the silencing of the thpg1 gene that encodes the endopolygalacturonase ThPG1 in T. harzianum T34 showed reduced tomato root colonization and diminished growth in minimal medium supplemented with pectin as carbon source [36]. These data together indicate that T. atroviride, T. virens, and tentatively other Trichoderma 
species respond to their host plant by secreting a common subset of lytic enzymes, mainly those related with the breakdown of cell wall components to colonize the plant roots.

\subsection{Arabidopsis and T. atroviride Secrete Proteins through Conventional and Non-Conventional} Secretion Pathways

Among the differentially modulated proteins in both secretomes, $71 \%$ of the Arabidopsis proteins and $40 \%$ of $T$. atroviride contain a putative $\mathrm{N}$-terminal SP, which is a secretion mark to release proteins to the medium, or for localization into or across the cell membrane. In eukaryotic cells, proteins with an SP are directed to the translocation apparatus of the ER and then, through vesicular transport from the ER to the Golgi, to be secreted outside of the cell [37]. This form of conventional secretion has been suggested for proteins secreted by maize plants in response to T. virens [26]. These findings suggest that during their interaction, Arabidopsis and T. atroviride deliver proteins to the extracellular milieu through conventional secretion systems. The putative mechanisms involving extracellular enzymes in the Arabidopsis-Trichoderma interaction are shown in our hypothetical model (Figure 9).

According to cellular component analysis, several Arabidopsis proteins were predicted to have an intracellular origin, such as JAL30 (jacalin-related lectin 30), RBL, GGAT1, PGP1B, FSD1 (Fe superoxide dismutase 1), and RCA (ribulose bisphosphate carboxylase/oxygenase activase) (Table 2). Interestingly, all these proteins were found in endomembrane compartments [38], and in EVs of Arabidopsis [28]. According to our analysis, all these proteins lack an SP and were potentially secreted by an unconventional secretion system (Table S2 and Figure 9).

Furthermore, our analysis revealed that in the T. atroviride secretome, $43 \%$ of the proteins lack an SP. Similar results were reported for T. virens proteins secreted in response to maize plants [26]. In some fungi, extracellular proteins that do not contain an SP are secreted by unconventional secretory pathways [39]. For example, the filamentous fungus Magnaporthe oryzae delivers cytoplasmic effector proteins into the host plant cell through a form of secretion that involves exocyst components and the Sso1 $t$-SNARE protein. In this form of secretion, the M. oryzae effector proteins are accumulated in a plant-derived membrane-rich interfacial structure called biotrophic interfacial complex and are ultimately delivered into the host cell [40]. Exocytic SNARE proteins have been reported to localize at subapical hyphae in $T$. reesei, which suggests the existence of an exocytic pathway for protein secretion in this fungus [41]. Interestingly, we found that a putative vesicle transport $t$-SNARE protein (JGI id: 146306) was accumulated in T. atroviride secretome at $96 \mathrm{~h}$ of co-culture with Arabidopsis (Table S2).

Additionally, some of the proteins identified in the secretome of T. atroviride may be released to the extracellular milieu through EVs. This idea is reinforced by a previous proteomic analysis of vesicles secreted by $T$. reesei during its growth in the presence of cellulose as a carbon source [42]. These authors reported the presence of 188 proteins inside vesicles, including glycosidases, peptidases, and chaperones. Here, we analyzed all the proteins reported by [42] to infer whether they lack an SP. Indeed, by using SignalP, we predicted that 177 out of 188 reported proteins (94\%) lack an SP (data not shown). All these findings together with our results suggest that unconventional secretion systems may be a mechanism by which Trichoderma spp. deliver proteins to the extracellular milieu to establish a crosstalk with their host plants. 


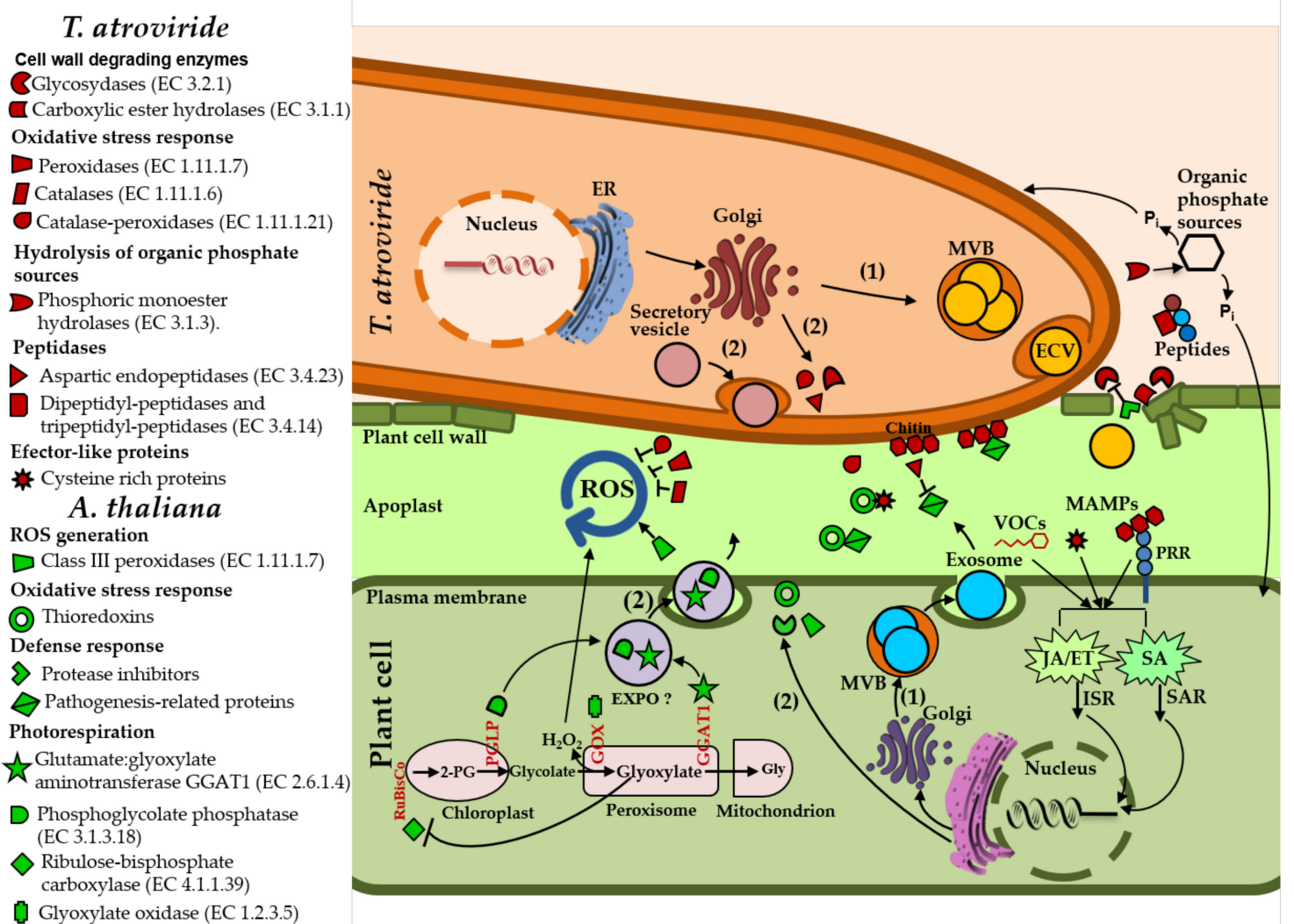

Figure 9. Hypothetical model representing the putative functions of Arabidopsis and T. atroviride secreted enzymes during their interaction. T. atroviride is recognized through its microbe-associated molecular patterns (MAMPs) (i.e., chitin) by pattern recognition receptors (PRRs) localized on the plant cell membrane. T. atroviride secretes effector-like proteins and volatile organic compounds (VOCs) into the apoplast. These events activate the JA/ET-dependent ISR-priming and SA-dependent SAR pathways. Subsequently, the accumulation of proteins related to plant defense, including enzymes and proteins with non-enzymatic function, secreted to the apoplast through conventional (outlined with 1) and unconventional secretion pathways that are enhanced (outlined with 2). On the T. atroviride side, it secretes an array of enzymes into the apoplast through conventional and unconventional secretion pathways to gain access to the first layers of the root epidermis. These include CWDEs that hydrolyze the plant cell wall polysaccharides. In response, the plant cell secretes protease inhibitors that act against some lytic enzymes liberated by the fungus to contain the cell wall damage. Subsequently, PR proteins with antimicrobial activity are secreted by the plant cell to control the proliferation of the fungus. Afterwards, the plant cell accumulates reactive oxygen species (ROS) into the apoplast, including $\mathrm{H}_{2} \mathrm{O}_{2}$, which is generated by apoplastic class III peroxidases. T. atroviride secrete antioxidant enzymes such as catalases and catalase-peroxidases into the apoplast to counteract the oxidative stress caused by ROS. Phosphoric monoester hydrolases are secreted by T. atroviride to hydrolyze organic phosphate sources to release inorganic phosphorous $\left(\mathrm{P}_{\mathrm{i}}\right)$, which can be taken up by the plant and by the fungus for their metabolism. Furthermore, in response to T. atroviride, the plant cell secretes enzymes involved in photorespiration. During photorespiration 2-PG is dephosphorylated in chloroplasts by PGLP to produce glycolate, which is oxidated by GOXs in peroxisomes to produce glyoxylate, which is finally transaminated to glycine (Gly) by the action of GGAT1. PGLP and GGAT1 are secreted by the plant cell, probably by EXPO. The secretion of GGAT1 to the apoplast causes an accumulation of glyoxylate into the cell, which can inhibit the enzyme RuBisCo. Question marks (?) indicate aspects that remain to be clarified. ER, endoplasmic reticulum; ECV, extracellular vesicle.

3.3. T. atroviride Secretes Enzymes Involved in Oxidative Stress Response, Cell Wall Degradation, Hydrolysis of Organic Phosphate Sources, and Peptidases during Its Interaction with Arabidopsis

In the T. atroviride secretome, we found several proteins potentially involved in oxidative stress response, which are represented mainly by enzymes acting on a peroxide as an acceptor, including catalases and catalase-peroxidases. Catalase-peroxidases possess both 
catalase and peroxidase activity, and they are thought to have a cell protective functions under oxidative stress [43]. In phytopathogenic fungi, catalases and peroxidases play important roles in defense against oxidative stress. For instance, the catalase-peroxidase CPXB secreted by $M$. oryzae plays a pivotal role in fungal defense against $\mathrm{H}_{2} \mathrm{O}_{2}$ accumulation in the epidermal cells of rice [44]. The enrichment of antioxidant enzymes in the T. atroviride secretome suggests a response of the fungus to cope with ROS produced by Arabidopsis, as shown for leaves in Figure 8.

The T. atroviride secretome analysis revealed the accumulation of many glycosidases, mainly during the early steps of interaction with Arabidopsis. These enzymes include cellulases, cellulose 1,4- $\beta$-cellobiosidases, and $\beta$-glucosidases (Table 1 and Table S2), which could be potentially involved in cell wall degradation of its host. Cellulases hydrolyze $\beta-1,4-$ D-glucan bonds of cellulose to produce cellobiose and other short oligosaccharides, which are hydrolyzed to glucose by $\beta$-glucosidases [45,46]. Other polysaccharide-hydrolyzing enzymes were increased in the T. atroviride secretome, including xyloglucan-specific, endo$\beta-1,4$-glucanases, and endo-1,4- $\beta$-xylanases, which hydrolyze the cell wall polysaccharides, xyloglucan, and xylan, respectively. In addition, other putative CWDEs were increased in T. atroviride secretome, such as a group of carboxylic ester hydrolases, an acetyl xylan esterase, and a cutinase. Acetyl xylan esterases remove side-chain residues from xylan backbones [47], whereas cutinases hydrolyze ester bonds of the plant polymer cutin [48]. In agreement with our results, an accumulation of extracellular glycosidases was reported in the T. virens secretome during its coculture with maize plants [26,27]. This supports the hypothesis that $T$. atroviride secretes CWDEs to disrupt the plant cell wall to gain access into the root epidermis and cortex to establish a mutualistic relationship (Figure 9).

The analysis of T. atroviride secretome revealed the presence of several enzymes involved in the hydrolysis of phosphate compounds, which was represented mainly by phosphoric monoester hydrolases. Phosphoric monoester hydrolases secreted by microbes can hydrolyze organic phosphate sources from the soil, such as inositol phosphates (phytates), nucleic acids, sugar phosphates, and phospholipids [49]. Reactions catalyzed by phosphoric monoester hydrolases such as phytases, acid phosphatases, and inositol-phosphate phosphatases release inorganic phosphorous $\left(\mathrm{P}_{\mathrm{i}}\right)$, which is taken up by plants and microorganisms for their metabolism [50]. Several studies have shown the capability of Trichoderma spp. to solubilize phosphate in vitro [51-53] and under stress conditions [54-56]. Phytases are phosphatases that hydrolyze phytic acid preferentially into inositol and $P_{i}[50]$, whereas acid phosphatases hydrolyze phosphomonoester and amides substrates, thereby transforming organic phosphate into a soluble inorganic form [57]. Phytase activity has been observed in several beneficial fungi, including Rhizopus microsporus [58], Funneliformis mosseae, Claroideoglomus etunicatum [49], and Trichoderma spp. [51]. We hypothesize that during T. atroviride interaction with its host plant, it secretes phosphoric monoester hydrolases to transform organic phosphate sources into a soluble inorganic form, which can be taken up by the fungus and the host plant for their metabolism (Figure 9).

The T. atroviride secretome analysis showed an array of peptidases, some of which were increased during its interaction with the plant. Peptidases have been studied mainly in phytopathogenic fungi. Plant pathogens secrete proteases that modify or degrade PR proteins with antimicrobial activity produced by the host plant, including chitinases, $\beta-1,3-$ glucanases, and proteases [59]. For instance, Verticillium dahliae secretes the Ser protease 1 (VdSSEP1) into the apoplast of cotton, where it hydrolyzes the extracellular chitinase Chi28 of the plant [60]. The Zn-metalloproteinase Fv-cmp from Fusarium verticillioides cleaves the class IV chitinases of the plant, which are plant defense proteins that bind and degrade the chitin of the fungal cell wall [61]. In the symbiotic fungi Oidiodendron maius, Rhizoscyphus ericae, and Meliniomyces bicolor, genes encoding proteases such as aspartic proteases, glutamic proteases, and subtilisins are upregulated during their interaction with their host plant [62]. Probably, T. atroviride secretes peptidases to inactivate the action of plant defense proteins or to obtain nitrogen sources from the degraded peptides for its growth (Figure 9). 
3.4. Arabidopsis Responds to the Presence of T. atroviride by Secreting Enzymes Involved in ROS Generation, Oxidative Stress Response, Defense Response, and Photorespiration

Several peroxidases with a known role in ROS generation were increased in the Arabidopsis secretome during its interaction with T. atroviride. In response to invading microbes, plants accumulate ROS in the apoplast, including $\mathrm{H}_{2} \mathrm{O}_{2}$, hydroxyl radicals $(\bullet \mathrm{OH})$, superoxide radicals $\left(\mathrm{O}_{2} \bullet^{-}\right)$, and nitric oxide $(\mathrm{NO})$, among others, leading to the so-called "oxidative burst" [63]. In Arabidopsis, the extracellular oxidative burst triggered by MAMPs involves the class III secretory peroxidases PRX33 and PRX34 [64,65]. In this regard, the $\mathrm{H}_{2} \mathrm{O}_{2}$ generated in the apoplast by PRX33 and PRX34 increases the colonization success of the phytopathogen Alternaria brassicicola [66]. Mechanisms involving $\mathrm{H}_{2} \mathrm{O}_{2}$ production have been described during plant-symbiotic fungi associations. For example, maize roots treated with the mycorrhizal fungus Glomus intraradices accumulate $\mathrm{H}_{2} \mathrm{O}_{2}$, probably to regulate the proliferation of the fungus within the plant roots [63]. Together, these data suggest that during its interaction with T. atroviride, the plant activates its ROSproducing systems as a mechanism to control the fungus proliferation within its roots (Figure 9).

Conversely, some peroxidases identified in the plant secretome, including PRX52, PRX69, and PRX71, were decreased through three times the interaction with T. atroviride. In agreement with these findings, a group of peroxidases are reduced in the root secretome of maize plants in response to the colonization by $T$. virens that correlates with a reduction in peroxidase activity, suggesting that $T$. virens manipulates its host stress oxidative response [26]. It is tempting to hypothesize that T. atroviride manipulates the Arabidopsis stress oxidative response as proposed for $T$. virens in maize seedlings.

A set of TRXs involved in oxidative stress response was increased in the Arabidopsis secretome in response to $T$. atroviride (Table 2 and Table S2). Some TRXs are secreted into the apoplast in response to pathogen attack or in response to abiotic stress, where they function as antioxidants, facilitating the reduction of other proteins $[67,68]$. TRXs play a major role in maintaining the cell in a reducing environment, interacting with target proteins to control their functions [69]. During their interaction with target proteins, TRXs reduce the disulfide bridges formed between cysteine residues using their highly conserved thiol groups $[68,70]$. It is tempting to speculate that during T. atroviride interaction with Arabidopsis, the plant secretes TRXs to regulate the activity of cysteine-rich extracellular proteins secreted by both organisms to maintain the redox homeostasis (Figure 9).

Plants have to fight against pathogens through the secretion of protease inhibitors that act against proteolytic enzymes liberated by the pathogen, including CWDEs [71,72]. According to the Arabidopsis secretome analysis, some protease inhibitors increased in response to T. atroviride, including the unusual serine protease inhibitor UPI, which is involved in plant defense against necrotrophic fungi [73] and the Kunitz trypsin inhibitor KTI1 involved in modulating programmed cell death (PCD) in plant-pathogen interactions and in defense against $P$. syringae [71]. Furthermore, Kunitz inhibitors can inhibit multiple types of hydrolytic enzymes, such as serine and cysteine proteases [72]. The secretion of protease inhibitors by Arabidopsis during its interaction with T. atroviride suggests that they could be working in the apoplast, inhibiting the activity of extracellular proteolytic enzymes of the fungus and helping to prevent the cell wall damage (Figure 9).

In Arabidopsis, a set of PR proteins with antimicrobial activity is secreted into the apoplast in response to pathogens and mutualistic fungi $[35,74]$. Here, several PR proteins increased in Arabidopsis secretome mainly at 24 and $48 \mathrm{~h}$ of interaction with T. atroviride, but not at later times. Overall, these findings suggest that $T$. atroviride is perceived as a pathogen by Arabidopsis at the first steps of the interaction, but it also suggests the suppression of plant immunity by the fungus at later times (Figure 9).

Here, we identified some enzymes related with photorespiration (Table 2 and Table S2). In the photorespiratory pathway, the key $\mathrm{CO}_{2}$ fixation enzyme ribulose bisphosphate carboxylase (RuBisCo) synthesizes the metabolite 2-phosphoglycolate (2-PG). Accumulation of higher levels of 2-PG in the cell causes several negative effects in the plant, such as the 
inhibition of the Calvin cycle enzyme triosephosphate isomerase [75]. The degradation of 2-PG requires the combined action of several enzymes of the photorespiratory pathway, including 2-phosphoglycolate phosphatases (PGLPs), glycolate oxidases (GOXs), and glutamate:glyoxylate aminotransferases (GGATs) [75]. Interestingly, we identified two enzymes related with the degradation of 2-PG, PGP1B, which dephosphorylates 2-PG to produce glycolate [76], and GGAT1, that catalyzes the conversion of glyoxylate to glycine during the photorespiration [77]. The degradation of glyoxylate is crucial, because its accumulation interferes with photosynthesis through the inhibition of RuBisCo [78]. We found that PGP1B was increased at the three times of interaction with the fungus, whereas GGAT1 was only accumulated at $48 \mathrm{~h}$ of co-culture (Table 2 and Table S2).

Our analysis indicated that RBCL was secreted by Arabidopsis when it was grown under control conditions (Table S1). However, this enzyme was decreased at 24 and 48 $\mathrm{h}$ of co-culture with the fungus (Table 2 and Table S2). We hypothesize that during the early steps of the interaction, the plant secretes into the apoplast enzymes related to photorespiration, including PGP1B and GGAT1, which causes the accumulation of glyoxylate, interfering with the activity of enzymes related with photosynthesis, including RuBisCo (Figure 9). This negative effect on photosynthesis is probably alleviated at late stages of the interaction when the beneficial relationship between both organisms is established. In this regard, some Trichoderma strains enhance the photosynthetic rate in their host plants $[79,80]$. Furthermore, photosynthetic enzymes were differentially accumulated in the cotyledons and shoots of cucumber and maize plants after root colonization by Trichoderma asperellum strain T34 and Trichoderma harzianum strain T22, respectively [81,82]. Since GGAT1, PGP1B, and RBCL are related with the photorespiration in photosynthetic tissues (i.e., in leaves), the identification of this enzymes in the plant root secretome was particularly interesting.

\subsection{GGAT1 Is Partially Required for Plant Growth Stimulation by T. atroviride}

In this study, we characterized a mutant allele of GGAT1 (ggat1-2) in Arabidopsis to test whether its product plays a role in plant growth stimulation by T. atroviride. Under our experimental conditions, ggat1-2 exhibited no apparent differences in the growth and development compared with Col-0 plants; however, it was reported that a different mutant allele of GGAT1 ( $g g t 1-1$ ) exhibited slight or no differences in growth phenotype compared with Col-0 plants under high- $\mathrm{CO}_{2}$ conditions [77,83]. Nevertheless, our results of plant-Trichoderma interaction showed that GGAT1 is partially required for plant growth stimulation by $T$. atroviride, but this phenotype is independent of root colonization by the fungus since similar results of CFU were determined for Col- 0 and ggat1-2 seedlings (Figure S5).

\subsection{GGAT1 Negatively Regulates the Plant Systemic Resistance against B. cinerea Tentatively through a Mechanism that Involves Altered $\mathrm{H}_{2} \mathrm{O}_{2}$ Production}

We found that ggat1-2 leaves of untreated seedlings with T. atroviride exhibited decreased damage provoked by B. cinerea compared to Col-0 plants. Contrastingly, ggat1-2 plants pretreated with $T$. atroviride showed a significant increase in lesion area than those of the Col-0 (Figure 7). These findings suggest that GGAT1 participates negatively in the resistance against $B$. cinerea and plays a minor role in inducing the plant systemic resistance by $T$. atroviride against the phytopathogen.

Previously, it was reported that a mutant allele of GGAT1 (ggt1-1) in Arabidopsis shows increased levels of $\mathrm{H}_{2} \mathrm{O}_{2}$ in leaves, which is consistent with the role of GGAT1 in photorespiration [34]. Indeed, we confirmed that the absence of GGAT1 in Arabidopsis causes a constitutive accumulation of $\mathrm{H}_{2} \mathrm{O}_{2}$ in leaves (Figure 8). GGAT1 is localized in peroxisomes [84]. Photorespiratory metabolism in peroxisomes produces $\mathrm{H}_{2} \mathrm{O}_{2}$ through the oxidation of glycolate to glyoxylate by GOXs [85]. However, the high production of $\mathrm{H}_{2} \mathrm{O}_{2}$ in ggat1-2 may be due to an indirect effect by the absence of GGAT1, since this protein is not directly involved in $\mathrm{H}_{2} \mathrm{O}_{2}$ production in the photorespiratory pathway [75]. This increased production of $\mathrm{H}_{2} \mathrm{O}_{2}$ in ggat1-2 may be confined to photosynthetic tissues as suggested [34], whereas it would not be expected in roots. Consistent with this hypothesis, 
GGAT1 transcripts were detected in mature leaves and in green siliques of Arabidopsis but not in roots [84]. We hypothesized that the altered production of $\mathrm{H}_{2} \mathrm{O}_{2}$ in ggat1-2 is linked with the enhanced resistance to $B$. cinerea observed in this mutant (Figure 9). Consistently with this hypothesis, high levels of $\mathrm{H}_{2} \mathrm{O}_{2}$ in tomato leaves are related to enhanced resistance to $B$. cinerea [86].

Furthermore, in addition to the altered levels of $\mathrm{H}_{2} \mathrm{O}_{2}$ in $g g t 1-1$, decreased levels of abscisic acid (ABA) are observed under polyethylene glycol (low water potential) or $\mathrm{NaCl}$ stresses [34]. In addition, it is well known that ABA accumulation antagonizes JA-ET signaling pathways [87]. Furthermore, ABA deficient mutants results in the upregulation of JA-ET responsive genes and correlates with enhanced resistance in Arabidopsis to the necrotrophic pathogen Fusarium oxysporum [87]. Based on these data, we hypothesize that increased levels of $\mathrm{H}_{2} \mathrm{O}_{2}$ in ggat1-2 plants could affect ABA accumulation as reported [34], leading to the upregulation of JA-ET responsive genes and triggering an enhanced resistance against $B$. cinerea.

In agreement with a previous report [88], DAB staining revealed that Col-0 seedlings co-cultivated with $T$. atroviride accumulate $\mathrm{H}_{2} \mathrm{O}_{2}$ in leaves. Furthermore, B. cinerea triggers the systemic accumulation of $\mathrm{H}_{2} \mathrm{O}_{2}$ in Col-0 leaves. Conversely, ggat1-2 exhibited reduced $\mathrm{H}_{2} \mathrm{O}_{2}$ levels in response to $B$. cinerea or T. atroviride compared to Col-0 under the same conditions (Figure 8), indicating that the production of $\mathrm{H}_{2} \mathrm{O}_{2}$ in the ggat1-2 mutant is negatively affected in response to the pathogen or the beneficial fungus. All these observations suggest that GGAT1 plays a role in regulating plant response to beneficial fungi and necrotrophic pathogens tentatively through a mechanism involved in $\mathrm{H}_{2} \mathrm{O}_{2}$ production.

Concluding, our quantitative proteomics and bioinformatic analysis of proteins secreted by Arabidopsis and T. atroviride indicate that during their interaction, both organisms secrete an array of proteins with enzymatic and non-enzymatic functions. T. atroviride secretes mainly glycosidases, aspartic endopeptidases, and dehydrogenases. In response to the presence of the fungus, the plant secretes peroxidases, cysteine endopeptidases, thioredoxins, and enzymes related to catabolism of secondary metabolites. Additionally, Arabidopsis secretes the photorespiratory enzyme glutamate:glyoxylate aminotransferase, GGAT1, which is partially required for plant growth stimulation and the induction of systemic resistance against Botrytis by T. atroviride. Finally, GGAT1 participates in the regulation of plant systemic resistance against $B$. cinerea tentatively through a mechanism involving $\mathrm{H}_{2} \mathrm{O}_{2}$ production.

\section{Materials and Methods}

\subsection{Plant and Fungal Growth Conditions for In Vitro Experiments}

Arabidopsis thaliana Columbia (Col-0) ecotype was used as the wt plant through this work. Seeds of ggat1-2 T-DNA insertional mutant (SALK_064982C) were obtained from the Arabidopsis Biological Resource Center (ABRC). ggat1-2 homozygous T-DNA insertional mutants were genotyped (Supplementary Figure S4) using the primers listed in Table S3. For in vitro experiments, $A$. thaliana $\mathrm{Col}-0$ seeds were sterilized by dry sterilization using $50 \mathrm{~mL}$ of commercial bleach (3.5\%) with $1 \mathrm{~mL}$ of hydrochloric acid $(32 \%)$ during four $\mathrm{h}$ in a closed chamber inside a fume hood. Sterilized seeds were stratified in sterile Petri dishes containing Murashige-Skoog (MS) medium (0.5× Murashige-Skoog medium, Duchefa Biochemie, Harleem, Netherlands), 2.5 mM MES buffer (Merck, Darmstadt, Germany) and $0.8 \%(w / v)$ plant agar (Duchefa Biochemie, Harleem, Netherlands), $\mathrm{pH}=5.7)$ in the dark at $4{ }^{\circ} \mathrm{C}$ for 2 days. Seeds were germinated on MS agar plate at $25^{\circ} \mathrm{C}$ under $16 / 8 \mathrm{~h}$ light/dark cycles $\left(130 \mu \mathrm{mol} \mathrm{m}^{-2} \mathrm{~s}^{-1}\right)$ for two days. Trichoderma atroviride IMI 206040 and Botrytis cinerea B05.10 [89] were routinely grown at $28^{\circ} \mathrm{C}$ on potato dextrose agar (PDA) (DIFCO) for 7 and 14 days, respectively. T. atroviride conidia were collected with sterile distilled water and adjusted at $1 \times 10^{6} \mathrm{~mL}^{-1}$, whereas $B$. cinerea conidia were adjusted to $5 \times 10^{5} \mathrm{~mL}^{-1}$ in inoculation buffer (per $40 \mathrm{~mL}$ of stock solution: Sucrose $1.37 \mathrm{~g}, 1 \mathrm{M}$ $\mathrm{KH}_{2} \mathrm{PO}_{4} 400 \mu \mathrm{L}, 12.5 \%$ Tween20: $80 \mu \mathrm{L}$ ) [90]. 


\subsection{Secretome System for Arabidopsis and T. atroviride Interaction Analysis}

Arabidopsis and T. atroviride were grown in a semi-hydroponic system adapted from [27]. Twenty $\mu \mathrm{L}$ micropipette tip holders were cut for supporting the germinated seeds and filled with MS medium ( $0.8 \%$ agar). Thirty 2-day-old seedlings were transferred to the tip holder filled with MS medium and placed inside magenta boxes (Figure S1). Twenty-five $\mathrm{mL}$ of MS medium were added to each semi-hydroponic system, and every four days, the growing medium was replaced by fresh medium. For T. atroviride inoculum, fifty $\mathrm{mL}$ of potato dextrose broth (PDB) medium were inoculated with a suspension of T. atroviride $\left(1 \times 10^{6}\right.$ conidia $\left./ \mathrm{mL}\right)$ and incubated with continuous shaking $(220 \mathrm{rpm})$ at $28^{\circ} \mathrm{C}$ for $72 \mathrm{~h}$. Actively growing mycelium was recovered by vacuum filtration through a $0.2 \mu \mathrm{m}$ filter and resuspended in $25 \mathrm{~mL}$ of MS medium supplemented with $0.05 \%(w / v)$ sucrose. Threeweek-old seedlings growing in the semi-hydroponic system box were inoculated with this fungal suspension. Uninoculated plants and T. atroviride were grown in separated semihydroponic systems as controls. The plants were maintained at $25^{\circ} \mathrm{C}$ and $16 / 8$ light/dark photoperiod with moderate shaking $(60 \mathrm{rpm})$ on an orbital shaker by four weeks.

\subsection{Secretome Samples Concentration}

The culture medium from semi-hydroponic system boxes was filtered through monofilament nylon mesh followed by a $0.22 \mu \mathrm{m}$ filter. Filtered secretomes were concentrated to a final volume of $500 \mu \mathrm{L}$ using Amicon Ultra-15 centrifugal filter units (cutoff $3000 \mathrm{Da}$; Merck Millipore, Darmstadt, Germany) in a benchtop centrifuge at $4{ }^{\circ} \mathrm{C}$. Then, the collected samples were treated with a protease inhibitor cocktail (Sigma, St. Louis, MO, USA). Total protein samples were verified for integrity by SDS-PAGE (15\% acrylamide). Samples were stored at $-80^{\circ} \mathrm{C}$ until their analysis.

\subsection{Identification of Secreted Proteins by Gel-Free Shotgun Proteomics}

Fifty $\mu \mathrm{L}$ of each Arabidopsis and Trichoderma control samples or $10 \mu \mathrm{L}$ of each interaction samples were used for the analysis. Shotgun protein identification and data analysis were performed according to Lamdan et al., 2015 [27]. The mass spectroscopy data from two biological replicates of each treatment at the different time conditions (24, 48 and $96 \mathrm{~h}$ ) were analyzed using MaxQuant software 1.5.2.8 (www.maxquant.org, accessed on 1 October 2018) for peak picking identification and quantitation using the same software. The identifications were filtered for proteins identified with an FDR $<0.01$. Complete proteomic data were deposited at the PRIDE database, with the accession number PXD023283.

\subsection{Bioinformatic Analysis of Secreted Proteins}

A comprehensive pipeline was performed to analyze secreted proteins and to identify their main features. The accession number of the identified proteins was uploaded at the UniProt database [91] and extracted in FASTA format with their UniProt ID. Sequences were submitted to Blast2Go [32] for Gene Ontology (GO) term analysis (cellular component, biological process, and molecular function). Blast2Go uses BLASTp [92] to find homologous proteins by comparing the submitted sequences against the non-redundant NCBI protein database. Subsequently, proteins were classified into functional families using HMMER v3.3.2 [93] and into enzymes according to the EC nomenclature system using BRENDA [33]. The presence of a signal peptide was predicted using SignalP v5.0 [94], and the presence of transmembrane helices was predicted using TMHMM v2.0 [95]. Proteins secreted by the classical pathway were predicted using SECRETOOL, which incorporates SignalP, and TMHMM for secretome prediction [29]. Prediction of non-classically secreted proteins was carried out using SecretomeP v2.0 [30] and OutCyte v1.0 [31].

\subsection{Plant-Growth Promotion and Plant-Pathogen Challenge Assays}

For plant growth promotion experiments, Col-0 and ggat1-2 seeds were sown into plastic pots containing 1:1:3 perlite:vermiculite:peat moss as substrate, stratified at $4{ }^{\circ} \mathrm{C}$ for 2 days, and then transferred to a growth room at $23^{\circ} \mathrm{C}$ under $12 \mathrm{~h}$ light $/ 12 \mathrm{~h}$ dark 
regime. Six-day-old seedlings were transferred to $6 \mathrm{~cm}$ plastic pots containing substrate and allowed to grow as mentioned above. Ten days after their transfer, plants were rootinoculated with $500 \mu \mathrm{L}$ of a suspension of $1 \times 10^{6}$ conidia $/ \mathrm{mL}$ of $T$. atroviride in $0.3 \times \mathrm{MS}$ liquid medium. Plant inoculated in the roots with $500 \mu \mathrm{L}$ of $0.3 \times$ MS were included as controls. Dry weight of 20 plants were determined individually at 21 post-treatments. Three independent experiments were performed.

Arabidopsis thaliana challenging experiments against $B$. cinerea were performed infecting three leaves of eight Col-0 or ggat1-2 plants pre-treated or not (control plants) with T. atroviride (18-days-post treatment) using $10 \mu \mathrm{L}$ of a suspension of $5 \times 10^{5}$ conidia of $B$. cinerea in inoculation buffer $\left(1 \mathrm{M} \mathrm{KH}_{2} \mathrm{PO}_{4}, 12.5 \%\right.$ Tween $20,1 \%$ Sucrose). Plants inoculated with inoculation buffer were included as controls. Digital images were taken at 6 days postinfection. The lesion area was calculated as pixels per lesion using ImageJ software and converted to $\mathrm{cm}^{2}$ using as reference a ruler for each image. Three independent experiments were performed.

\subsection{Detection of Hydrogen Peroxide $\left(\mathrm{H}_{2} \mathrm{O}_{2}\right)$ in Arabidopsis Leaves Using 3,3-diaminobenzidine (DAB)}

In situ $\mathrm{H}_{2} \mathrm{O}_{2}$ detection was performed using 12-day-old seedlings (Col-0 and ggat1-2 lines) grown under control conditions using 3,3-diaminobenzidine (DAB) staining (SigmaAldrich) as previously reported [96]. Leaves were infected with $1 \mu \mathrm{L}$ of a suspension of $5 \times 10^{5}$ conidia of $B$. cinerea or with inoculation buffer (control). In parallel, Col-0 and ggat1-2 seedlings pretreated or not with T. atroviride for $72 \mathrm{~h}$ were infected with B. cinerea or with inoculation buffer. Uninoculated leaves were detached after $24 \mathrm{~h}$ and infiltrated with DAB. Samples were observed under microscope at $4 \mathrm{x}$ magnification. Ten seedlings of each line were analyzed by treatment. Assays were repeated twice. Ten representative leaves of each condition were selected for DAB staining intensity determination using Fiji, an image processing package distributed by ImageJ software (https:/ /imagej.net/Fiji, accessed on 29 May 2021).

\subsection{Colonization Assay}

Thirty 15-day-old Col-0 and ggat1-2 plants grown on $0.5 \mathrm{X}$ MS agar plate at $25{ }^{\circ} \mathrm{C}$ under $16 / 8 \mathrm{~h} \mathrm{light/dark} \mathrm{cycles}\left(130 \mu \mathrm{mol} \mathrm{m} \mathrm{m}^{-2} \mathrm{~s}^{-1}\right)$ were immersed in a T. atroviride $1 \times 10^{7}$ conidia/mL suspension for $5 \mathrm{~min}$. Col-0 and ggat1-2 plants were placed on paper filters contained into Petri dishes moisturized with $3 \mathrm{~mL}$ of sterile distilled water. Then, plants were incubated $72 \mathrm{~h}$ as described above. Plants treated with sterile distilled water were included as control. Detached roots were weighed and immersed into $1 \% \mathrm{NaOCl}$ (commercial bleach diluted with sterile distilled water) for $2 \mathrm{~min}$. Then, roots were washed three times with sterile distilled water for 2 min each and homogenized using a mortar with $1 \mathrm{~mL}$ of PBS buffer $\left(5 \mathrm{mM} \mathrm{NaCl}, 2.7 \mathrm{mM} \mathrm{KCl}, 10 \mathrm{mM} \mathrm{Na}_{2} \mathrm{HPO}_{4}, 1.8 \mathrm{mM} \mathrm{KH}_{2} \mathrm{PO}_{4}, \mathrm{pH}\right.$ 7.2). Two hundred $\mu \mathrm{L}$ of the homogenate were plated on PDA plates supplemented with $50 \mu \mathrm{g} / \mathrm{mL}$ of chloramphenicol and $0.5 \%$ Triton and the colony-forming units (CFU) were assessed at $72 \mathrm{~h}$.

Supplementary Materials: The following are available online at https:/ /www.mdpi.com/article/10 $.3390 /$ ijms22136804/s1.

Author Contributions: Formal analysis, S.C.-F., B.A.H., M.d.C.G.-L., S.J.-M. and C.O.-V.; Funding acquisition, S.C.-F., B.A.H.; Investigation, M.d.C.G.-L., S.J.-M. and M.D.-C.; Methodology, M.d.C.G.L., S.J.-M., M.D.-C., B.A.H., C.O.-V. and T.Z.; Software, S.C.-F.; Writing-original draft, M.d.C.G.-L. and S.J.-M.; Writing-review and editing, S.C.-F., B.A.H., M.D.-C., C.O.-V. and T.Z. All authors have read and agreed to the published version of the manuscript.

Funding: This work was supported by grant IFC-2016-1538 to S.C.-F., M.d.C.G.-L., S.J.-M., M.D.-C. and S.C.-F. are supported by IFC-2016-1538. M.d.C.G.-L., S.J.-M. and M.D.-C. are indebted to CONACYT for doctoral (369245) and postdoctoral fellowships (335499 and IFC-2016-1538) respectively.

Institutional Review Board Statement: Not applicable. 
Informed Consent Statement: Not applicable.

Data Availability Statement: Complete proteomic data were deposited at the PRIDE database, with the accession number PXD023283.

Acknowledgments: The authors wish to thank Nicolás Gómez-Hernández for his technical support.

Conflicts of Interest: The authors declare no conflict of interest.

\section{References}

1. Rehman Hakeem, K.; Akhtar Sayeed, M. Plant, Soil and Microbes; Springer: Berlin/Heidelberg, Germany, 2016; Volume 2, ISBN 9783319295725.

2. Malinovsky, F.G.; Fangel, J.U.; Willats, W.G.T. The role of the cell wall in plant immunity. Front. Plant Sci. 2014, 5, 1-12. [CrossRef] [PubMed]

3. De-la-Pena, C.; Badri, D.V.; Loyola-Vargas, V.M. Plant root secretions and their interactions with neighbors. In Secretions and Exudates in Biological Systems; Springer: Berlin/Heidelberg, Germany, 2012; pp. 1-26. [CrossRef]

4. Kubicek, C.P.; Starr, T.L.; Glass, N.L. Plant cell wall-degrading enzymes and their secretion in plant-pathogenic fungi. Annu. Rev. Phytopathol. 2014, 52, 427-451. [CrossRef] [PubMed]

5. Druzhinina, I.S.; Chenthamara, K.; Zhang, J.; Atanasova, L.; Yang, D.; Miao, Y.; Rahimi, M.J.; Grujic, M.; Cai, F.; Pourmehdi, S.; et al. Massive lateral transfer of genes encoding plant cell wall-degrading enzymes to the mycoparasitic fungus Trichoderma from its plant-associated hosts. PLoS Genet. 2018, 14, 1-33. [CrossRef] [PubMed]

6. Pieterse, M.J.; Zamioudis, C.; Berendsen, R.L.; Weller, D.M.; Van Wees, S.C.M.; Bakker, P.A.H.M. Induced Systemic Resistance by Beneficial Microbes. Annu. Rev. Phytopathol. 2014, 52, 347-375. [CrossRef]

7. Ning, Y.; Liu, W.; Wang, G.L. Balancing Immunity and Yield in Crop Plants. Trends Plant Sci. 2017, 22, 1069-1079. [CrossRef]

8. Bürger, M.; Chory, J. Stressed out about Hormones: How Plants Orchestrate Immunity. Cell Host Microbe 2019, 26, 163-172. [CrossRef]

9. Burdett, H.; Bentham, A.R.; Williams, S.J.; Dodds, P.N.; Anderson, P.A.; Banfield, M.J.; Kobe, B. The Plant "Resistosome": Structural Insights into Immune Signaling. Cell Host Microbe 2019, 26, 193-201. [CrossRef]

10. Ramirez-prado, J.S.; Abulfaraj, A.A.; Rayapuram, N.; Benhamed, M. Plant Immunity: From Signaling to Epigenetic Control of Defense. Trends Plant Sci. 2018, 23, 833-844. [CrossRef]

11. Tanveer, T.; Shaheen, K.; Parveen, S.; Kazi, A.G.; Ahmad, P. Plant secretomics: Identification, isolation, and biological significance under environmental stress. Plant Signal. Behav. 2014, 9, 37-41. [CrossRef]

12. Davis, D.J.; Kang, B.-H.; Heringer, A.S.; Wilkop, T.E.; Drakakaki, G. Unconventional Protein Secretion in Plants; Pompa, A., De Marchis, F., Eds.; Humana Press: New York, NY, USA, 2016; Volume 1459, ISBN 9781493938025.

13. Rabouille, C. Pathways of Unconventional Protein Secretion. Trends Cell Biol. 2017, 27, 230-240. [CrossRef]

14. Plett, J.M.; Daguerre, Y.; Wittulsky, S.; Vayssières, A.; Deveau, A.; Melton, S.J. Effector MiSSP7 of the mutualistic fungus Laccaria bicolor stabilizes the Populus JAZ6 protein and represses jasmonic acid (JA) responsive genes. Proc. Natl. Acad. Sci. USA 2014, 111. [CrossRef]

15. Rebolledo-Prudencio, O.G.; Dautt-Castro, M.; Estrada-Rivera, M.; del González-López, M.C.; Jijón-Moreno, S.; Casas-Flores, S. Trichoderma in the rhizosphere: An approach toward a long and successful symbiosis with plants. In New and Future Developments in Microbial Biotechnology and Bioengineering; Elsevier: Amsterdam, The Netherlands, 2020; pp. 3-38, ISBN 9780128194539.

16. Kloppholz, S.; Kuhn, H.; Requena, N. Report A Secreted Fungal Effector of Glomus intraradices Promotes Symbiotic Biotrophy. Curr. Biol. 2011, 21, 1204-1209. [CrossRef]

17. Jaroszuk-ściseł, J.; Tyśkiewicz, R.; Nowak, A.; Ozimek, E.; Majewska, M.; Hanaka, A.; Tyśkiewicz, K.; Pawlik, A.; Janusz, G. Phytohormones (Auxin, gibberellin) and ACC deaminase in vitro synthesized by the mycoparasitic Trichoderma DEMTKZ3A0 strain and changes in the level of auxin and plant resistance markers in wheat seedlings inoculated with this strain conidia. Int. J. Mol. Sci. 2019, 20, 4923. [CrossRef] [PubMed]

18. Bononi, L.; Chiaramonte, J.B.; Pansa, C.C.; Moitinho, M.A.; Melo, I.S. Phosphorus-solubilizing Trichoderma spp. from Amazon soils improve soybean plant growth. Sci. Rep. 2020, 10, 1-13. [CrossRef] [PubMed]

19. Estrada-Rivera, M.; del Rocha-Medina, M.C.; Pérez-Robles, D.A.; Casas-Flores, S.; Rebolledo-Prudencio, O.G.; del GonzálezLópez, M.C. Trichoderma histone deacetylase HDA-2 modulates multiple responses in Arabidopsis. Plant Physiol. $2019,52$. [CrossRef] [PubMed]

20. Phoka, N.; Suwannarach, N.; Lumyong, S.; Ito, S.I.; Matsui, K.; Arikit, S.; Sunpapao, A. Role of volatiles from the endophytic fungus Trichoderma asperelloides psu-p1 in biocontrol potential and in promoting the plant growth of Arabidopsis thaliana. J. Fungi 2020, 6, 341. [CrossRef]

21. Salas-Marina, M.A.; Isordia-Jasso, M.I.; Islas-Osuna, M.A.; Delgado-Sánchez, P.; Jiménez-Bremont, J.F.; Rodríguez-Kessler, M.; Rosales-Saavedra, M.T.; Herrera-Estrella, A.; Casas-Flores, S. The Epl1 and Sm1 proteins from Trichoderma atroviride and Trichoderma virens differentially modulate systemic disease resistance against different life style pathogens in Solanum lycopersicum. Front. Plant Sci. 2015, 6, 1-13. [CrossRef] [PubMed]

22. Aamir, M.; Kashyap, S.P.; Zehra, A.; Dubey, M.K.; Singh, V.K.; Ansari, W.A.; Upadhyay, R.S.; Singh, S. Trichoderma erinaceum Bio-Priming Modulates the WRKYs Defense Programming in Tomato Against the Fusarium oxysporum f. sp. lycopersici (Fol) Challenged Condition. Front. Plant Sci. 2019, 10. [CrossRef] 
23. Rebolledo-Prudencio, O.G. La Maquinaria de Silenciamiento Génico Mediada por sRNAs de Arabidopsis thaliana y su Papel en el Establecimiento de una Relación Benéfica con Trichoderma atroviride. Master's Thesis, Instituto Potosino de Investigación Científica y Tecnológica (IPICYT), San Luis Potosí, Mexico, 2015.

24. Der Wang, K.; Gorman, Z.; Huang, P.C.; Kenerley, C.M.; Kolomiets, M.V. Trichoderma virens colonization of maize roots triggers rapid accumulation of 12-oxophytodienoate and two $\alpha$-ketols in leaves as priming agents of induced systemic resistance. Plant Signal. Behav. 2020, 18-22. [CrossRef]

25. Van Oosten, V.R.; Bodenhausen, N.; Reymond, P.; Van Pelt, J.A.; Van Loon, L.C.; Dicke, M.; Pieterse, C.M.J. Differential effectiveness of microbially induced resistance against herbivorous insects in Arabidopsis. Mol. Plant-Microbe Interact. 2008, 21, 919-930. [CrossRef]

26. Nogueira-Lopez, G.; Greenwood, D.R.; Middleditch, M.; Winefield, C.; Eaton, C.; Steyaert, J.M. The Apoplastic Secretome of Trichoderma virens During Interaction with Maize Roots Shows an Inhibition of Plant Defence and Scavenging Oxidative Stress Secreted Proteins. Front. Plant Sci. 2018, 9, 1-23. [CrossRef]

27. Lamdan, N.; Shalaby, S.; Ziv, T.; Kenerley, C.M.; Horwitz, B.A. Secretome of Trichoderma Interacting with Maize Roots: Role in Induced Systemic Resistance. Mol. Cell. Proteom. 2015, 14, 1054-1063. [CrossRef] [PubMed]

28. Rutter, B.D.; Innes, R.W. Extracellular vesicles isolated from the leaf apoplast carry stress-response proteins. Plant Physiol. 2017, 173, 728-741. [CrossRef]

29. Cortázar, A.R.; Aransay, A.M.; Alfaro, M.; Oguiza, J.A.; Lavín, J.L. SECRETOOL: Integrated secretome analysis tool for fungi. Amino Acids 2014, 46, 471-473. [CrossRef]

30. Bendtsen, J.D.; Jensen, L.J.; Blom, N.; Von Heijne, G.; Brunak, S. Feature-based prediction of non-classical and leaderless protein secretion. Protein Eng. Des. Sel. 2004, 17, 349-356. [CrossRef] [PubMed]

31. Zhao, L.; Poschmann, G.; Waldera-Lupa, D.; Rafiee, N.; Kollmann, M.; Stühler, K. OutCyte: A novel tool for predicting unconventional protein secretion. Sci. Rep. 2019, 9, 1-9. [CrossRef] [PubMed]

32. Conesa, A.; Götz, S.; García-Gómez, J.M.; Terol, J.; Talón, M.; Robles, M. Blast2GO: A universal tool for annotation, visualization and analysis in functional genomics research. Bioinformatics 2005, 21, 3674-3676. [CrossRef] [PubMed]

33. Schomburg, I.; Chang, A.; Ebeling, C.; Gremse, M.; Heldt, C.; Huhn, G.; Schomburg, D. BRENDA, the enzyme database: Updates and major new developments. Nucleic Acids Res. 2004, 32, 431-433. [CrossRef]

34. Verslues, P.E.; Kim, Y.S.; Zhu, J.K. Altered ABA, proline and hydrogen peroxide in an Arabidopsis glutamate:glyoxylate aminotransferase mutant. Plant Mol. Biol. 2007, 64, 205-217. [CrossRef]

35. Thürich, J.; Meichsner, D.; Furch, A.C.U.; Pfalz, J.; Krüger, T.; Kniemeyer, O.; Brakhage, A.; Oelmüller, R. Arabidopsis thaliana responds to colonisation of Piriformospora indica by secretion of symbiosis-specific proteins. PLoS ONE 2018, 13, e209658. [CrossRef]

36. Morán-Diez, E.; Hermosa, R.; Ambrosino, P.; Cardoza, R.E.; Gutiérrez, S.; Lorito, M.; Monte, E. The ThPG1 Endopolygalacturonase Is Required for the Trichoderma harzianum-Plant Beneficial Interaction. Mol. Plant Microbe Interact. 2009, 22, 1021-1031. [CrossRef]

37. Sun, X.; Su, X. Harnessing the knowledge of protein secretion for enhanced protein production in filamentous fungi. World $J$. Microbiol. Biotechnol. 2019, 35, 1-10. [CrossRef] [PubMed]

38. Heard, W.; Sklenář, J.; Tomé, D.F.A.; Robatzek, S.; Jones, A.M.E. Identification of regulatory and cargo proteins of endosomal and secretory pathways in Arabidopsis thaliana by proteomic dissection. Mol. Cell. Proteom. 2015, 14, 1796-1813. [CrossRef]

39. Miura, N.; Ueda, M. Evaluation of Unconventional Protein Secretion by Saccharomyces cerevisiae and other Fungi. Cells 2018, 7, 128. [CrossRef] [PubMed]

40. Giraldo, M.C.; Dagdas, Y.F.; Gupta, Y.K.; Mentlak, T.A.; Yi, M.; Martinez-Rocha, A.L.; Saitoh, H.; Terauchi, R.; Talbot, N.J.; Valent, B. Two distinct secretion systems facilitate tissue invasion by the rice blast fungus Magnaporthe oryzae. Nat. Commun. 2013, 4, 1-12. [CrossRef]

41. Valkonen, M.; Kalkman, E.R.; Saloheimo, M.; Penttilä, M.; Read, N.D.; Duncan, R.R. Spatially segregated SNARE protein interactions in living fungal cells. J. Biol. Chem. 2007, 282, 22775-22785. [CrossRef]

42. De Paula, R.G.; Antoniêto, A.C.C.; Nogueira, K.M.V.; Ribeiro, L.F.C.; Rocha, M.C.; Malavazi, I.; Almeida, F.; Silva, R.N. Extracellular vesicles carry cellulases in the industrial fungus Trichoderma reesei. Biotechnol. Biofuels 2019, 12, 1-14. [CrossRef]

43. Smulevich, G.; Jakopitsch, C.; Droghetti, E.; Obinger, C. Probing the structure and bifunctionality of catalase-peroxidase (KatG). J. Inorg. Biochem. 2006, 100, 568-585. [CrossRef]

44. Tanabe, S.; Ishii-Minami, N.; Saitoh, K.I.; Otake, Y.; Kaku, H.; Shibuya, N.; Nishizawa, Y.; Minami, E. The role of catalaseperoxidase secreted by Magnaporthe oryzae during early infection of rice cells. Mol. Plant-Microbe Interact. 2011, $24,163-171$. [CrossRef] [PubMed]

45. Houfani, A.A.; Anders, N.; Spiess, A.C.; Baldrian, P.; Benallaoua, S. Insights from enzymatic degradation of cellulose and hemicellulose to fermentable sugars-A review. Biomass Bioenergy 2020, 134, 105481. [CrossRef]

46. Singh, G.; Verma, A.K.; Kumar, V. Catalytic properties, functional attributes and industrial applications of $\beta$-glucosidases. 3 Biotech 2016, 6, 1-14. [CrossRef]

47. Yang, Y.; Zhu, N.; Yang, J.; Lin, Y.; Liu, J.; Wang, R.; Wang, F.; Yuan, H. A novel bifunctional acetyl xylan esterase/arabinofuranosidase from Penicillium chrysogenum P33 enhances enzymatic hydrolysis of lignocellulose. Microb. Cell Fact. 2017, 16, 1-12. [CrossRef]

48. Chen, S.; Su, L.; Chen, J.; Wu, J. Cutinase: Characteristics, preparation, and application. Biotechnol. Adv. 2013, 31, 1754-1767. [CrossRef]

49. Wang, X.X.; Hoffland, E.; Feng, G.; Kuyper, T.W. Phosphate uptake from phytate due to hyphae-mediated phytase activity by arbuscular mycorrhizal maize. Front. Plant Sci. 2017, 8, 1-8. [CrossRef] 
50. Corrêa, T.L.R.; de Araújo, E.F. Fungal phytases: From genes to applications. Braz. J. Microbiol. 2020, 51, 1009-1020. [CrossRef] [PubMed]

51. Saravanakumar, K.; Arasu, V.S.; Kathiresan, K. Effect of Trichoderma on soil phosphate solubilization and growth improvement of Avicennia marina. Aquat. Bot. 2013, 104, 101-105. [CrossRef]

52. Mara, P.R.; Isabel, C.M.C.J.; dos Luiz, C.R.S.; Marcos, A.S.; Flvia, D.P.; Edson, L.S.; Fabiano, G.S. Phosphate solubilization and phytohormone production by endophytic and rhizosphere Trichoderma isolates of guanandi (Calophyllum brasiliense Cambess). Afr. J. Microbiol. Res. 2014, 8, 2616-2623. [CrossRef]

53. Chagas, L.F.B.; De Castro, H.G.; Colonia, B.S.O.; De Carvalho Filho, M.R.; Miller, L.D.O.; Chagas, A.F.J. Efficiency of Trichoderma spp. as a growth promoter of cowpea (Vigna unguiculata) and analysis of phosphate solubilization and indole acetic acid synthesis. Rev. Bras. Bot. 2016, 39, 437-445. [CrossRef]

54. Rawat, R.; Tewari, L. Effect of abiotic stress on phosphate solubilization by biocontrol fungus Trichoderma sp.. Curr. Microbiol. 2011, 62, 1521-1526. [CrossRef]

55. Zhao, L.; Liu, Q.; Zhang, Y.Q.; Cui, Q.Y.; Liang, Y.C. Effect of acid phosphatase produced by Trichoderma asperellum Q1 on growth of Arabidopsis under salt stress. J. Integr. Agric. 2017, 16, 1341-1346. [CrossRef]

56. Tandon, A.; Fatima, T.; Anshu; Shukla, D.; Tripathi, P.; Srivastava, S.; Singh, P.C. Phosphate solubilization by Trichoderma koningiopsis (NBRI-PR5) under abiotic stress conditions. J. King Saud Univ. Sci. 2020, 32, 791-798. [CrossRef]

57. Schenk, G.; Mitić, N.Š.; Hanson, G.R.; Comba, P. Purple acid phosphatase: A journey into the function and mechanism of a colorful enzyme. Coord. Chem. Rev. 2013, 257, 473-482. [CrossRef]

58. De Oliveira Ornela, P.H.; Souza Guimarães, L.H. Purification and characterization of an alkalistable phytase produced by Rhizopus microsporus var. microsporus in submerged fermentation. Process Biochem. 2019, 81, 70-76. [CrossRef]

59. Jashni, M.K.; Mehrabi, R.; Collemare, J.; Mesarich, C.H.; de Wit, P.J.G.M. The battle in the apoplast: Further insights into the roles of proteases and their inhibitors in plant-pathogen interactions. Front. Plant Sci. 2015, 6, 1-7. [CrossRef] [PubMed]

60. Han, L.B.; Li, Y.B.; Wang, F.X.; Wang, W.Y.; Liu, J.; Wu, J.H.; Zhong, N.Q.; Wu, S.J.; Jiao, G.L.; Wang, H.Y.; et al. The Cotton Apoplastic Protein CRR1 stabilizes chitinase 28 to facilitate defense against the fungal pathogen Verticillium dahliae. Plant Cell 2019, 31, 520-536. [CrossRef]

61. Slavokhotova, A.A.; Naumann, T.A.; Price, N.P.J.; Rogozhin, E.A.; Andreev, Y.A.; Vassilevski, A.A.; Odintsova, T.I. Novel mode of action of plant defense peptides-Hevein-like antimicrobial peptides from wheat inhibit fungal metalloproteases. FEBS J. 2014, 281, 4754-4764. [CrossRef] [PubMed]

62. Martino, E.; Morin, E.; Grelet, G.A.; Kuo, A.; Kohler, A.; Daghino, S.; Barry, K.W.; Cichocki, N.; Clum, A.; Dockter, R.B.; et al. Comparative genomics and transcriptomics depict ericoid mycorrhizal fungi as versatile saprotrophs and plant mutualists. New Phytol. 2018, 217, 1213-1229. [CrossRef]

63. Nanda, A.K.; Andrio, E.; Marino, D.; Pauly, N.; Dunand, C. Reactive oxygen species during plant-microorganism early interactions. J. Integr. Plant Biol. 2010, 52, 195-204. [CrossRef]

64. Daudi, A.; Cheng, Z.; O’Brien, J.A.; Mammarella, N.; Khan, S.; Ausubel, F.M.; Bolwell, G.P. The Apoplastic Oxidative Burst Peroxidase in Arabidopsis Is a Major Component of Pattern-Triggered Immunity. Plant 2012, 24, 275-287. [CrossRef]

65. O'Brien, J.A.; Daudi, A.; Finch, P.; Butt, V.S.; Whitelegge, J.P.; Souda, P.; Ausubel, F.M.; Bolwell, G.P. A peroxidase-dependent apoplastic oxidative burst in cultured arabidopsis cells functions in MAMP-elicited defense. Plant Physiol. 2012, 158, $2013-2027$. [CrossRef] [PubMed]

66. Kámán-Tóth, E.; Dankó, T.; Gullner, G.; Bozsó, Z.; Palkovics, L.; Pogány, M. Contribution of cell wall peroxidase- and NADPH oxidase-derived reactive oxygen species to Alternaria brassicicola-induced oxidative burst in Arabidopsis. Mol. Plant Pathol. 2019, 20, 485-499. [CrossRef]

67. Li, Y.B.; Han, L.B.; Wang, H.Y.; Zhang, J.; Sun, S.T.; Feng, D.Q.; Yang, C.L.; Sun, Y.D.; Zhong, N.Q.; Xia, G.X. The thioredoxin GbNRX1 plays a crucial role in homeostasis of apoplastic reactive oxygen species in response to Verticillium dahliae infection in cotton. Plant Physiol. 2016, 170, 2392-2406. [CrossRef]

68. Zhang, C.J.; Zhao, B.C.; Ge, W.N.; Zhang, Y.F.; Song, Y.; Sun, D.Y.; Guo, Y. An apoplastic h-type thioredoxin is involved in the stress response through regulation of the apoplastic reactive oxygen species in rice. Plant Physiol. 2011, 157, 1884-1899. [CrossRef] [PubMed]

69. Lee, S.; Kim, S.M.; Lee, R.T. Thioredoxin and thioredoxin target proteins: From molecular mechanisms to functional significance. Antioxid. Redox Signal. 2013, 18, 1165-1207. [CrossRef] [PubMed]

70. Patwari, P.; Higgins, L.J.; Chutkow, W.A.; Yoshioka, J.; Lee, R.T. The interaction of thioredoxin with Txnip: Evidence for formation of a mixed disulfide by disulfide exchange. J. Biol. Chem. 2006, 281, 21884-21891. [CrossRef] [PubMed]

71. Li, J.; Brader, G.; Palva, E.T. Kunitz trypsin inhibitor: An antagonist of cell death triggered by phytopathogens and fumonisin B1 in Arabidopsis. Mol. Plant 2008, 1, 482-495. [CrossRef] [PubMed]

72. Renko, M.; Sabotič, J.; Turk, D. $\beta$-Trefoil inhibitors—From the work of Kunitz onward. Biol. Chem. 2012, 393, 1043-1054. [CrossRef]

73. Laluk, K.; Mengiste, T. The Arabidopsis extracellular UNUSUAL SERINE PROTEASE INHIBITOR functions in resistance to necrotrophic fungi and insect herbivory. Plant J. 2011, 68, 480-494. [CrossRef]

74. Jain, D.; Khurana, J.P. Role of pathogenesis-related (PR) proteins in plant defense mechanism. Mol. Asp. Plant Pathog. Interact. 2018, 265-281. [CrossRef]

75. Bauwe, H. Photorespiration-Damage Repair Pathway of the Calvin-Benson Cycle. In Plant Mitochondria; Logan, D., Ed.; Wiley Online Library: Hoboken, NJ, USA, 2018; Volume 50, pp. 293-342. ISBN 9781119312994. 
76. Schwarte, S.; Bauwe, H. Identification of the photorespiratory 2-phosphoglycolate phosphatase, PGLP1, in Arabidopsis. Plant Physiol. 2007, 144, 1580-1586. [CrossRef]

77. Igarashi, D.; Miwa, T.; Seki, M.; Kobayashi, M.; Kato, T.; Tabata, S.; Shinozaki, K.; Ohsumi, C. Identification of photorespiratory glutamate:glyoxylate aminotransferase (GGAT) gene in Arabidopsis. Plant J. 2003, 33, 975-987. [CrossRef]

78. Lu, Y.; Li, Y.; Yang, Q.; Zhang, Z.; Chen, Y.; Zhang, S.; Peng, X.X. Suppression of glycolate oxidase causes glyoxylate accumulation that inhibits photosynthesis through deactivating Rubisco in rice. Physiol. Plant. 2014, 150, 463-476. [CrossRef] [PubMed]

79. Fiorini, L.; Guglielminetti, L.; Mariotti, L.; Curadi, M.; Picciarelli, P.; Scartazza, A.; Sarrocco, S.; Vannacci, G. Trichoderma harzianum T6776 modulates a complex metabolic network to stimulate tomato cv. Micro-Tom growth. Plant Soil 2016, 400, 351-366. [CrossRef]

80. Oljira, A.M.; Hussain, T.; Waghmode, T.R.; Zhao, H.; Sun, H.; Liu, X.; Wang, X.; Liu, B. Trichoderma enhances net photosynthesis, water use efficiency, and growth of wheat (Triticum aestivum L.) under salt stress. Microorganisms 2020, $8,1565$. [CrossRef] [PubMed]

81. Segarra, G.; Casanova, E.; Bellido, D.; Odena, M.A.; Oliveira, E.; Trillas, I. Proteome, salicylic acid, and jasmonic acid changes in cucumber plants inoculated with Trichoderma asperellum strain T34. Proteomics 2007, 7, 3943-3952. [CrossRef] [PubMed]

82. Shoresh, M.; Harman, G.E. The molecular basis of shoot responses of maize seedlings to Trichoderma harzianum T22 inoculation of the root: A proteomic approach. Plant Physiol. 2008, 147, 2147-2163. [CrossRef] [PubMed]

83. Dellero, Y.; Lamothe-Sibold, M.; Jossier, M.; Hodges, M. Arabidopsis thaliana ggt1 photorespiratory mutants maintain leaf carbon/nitrogen balance by reducing RuBisCO content and plant growth. Plant J. 2015, 83, 1005-1018. [CrossRef] [PubMed]

84. Liepman, A.H.; Olsen, L.J. Alanine aminotransferase homologs catalyze the glutamate:Glyoxylate aminotransferase reaction in peroxisomes of Arabidopsis. Plant Physiol. 2003, 131, 215-227. [CrossRef] [PubMed]

85. Dellero, Y.; Jossier, M.; Schmitz, J.; Maurino, V.G.; Hodges, M. Photorespiratory glycolate-glyoxylate metabolism. J. Exp. Bot. 2016, 67, 3041-3052. [CrossRef]

86. Asselbergh, B.; Curvers, K.; França, S.C.; Audenaert, K.; Vuylsteke, M.; Van Breusegem, F.; Höfte, M. Resistance to Botrytis cinerea in sitiens, an abscisic acid-deficient tomato mutant, involves timely production of hydrogen peroxide and cell wall modifications in the epidermis. Plant Physiol. 2007, 144, 1863-1877. [CrossRef]

87. Anderson, J.P.; Badruzsaufari, E.; Schenk, P.M.; Manners, J.M.; Desmond, O.J.; Ehlert, C.; Maclean, D.J.; Ebert, P.R.; Kazan, K. Antagonistic interaction between abscisic acid and jasmonate-ethylene signaling pathways modulates defense gene expression and disease resistance in Arabidopsis. Plant Cell 2004, 16, 3460-3479. [CrossRef]

88. Contreras-Cornejo, H.A.; Macías-Rodríguez, L.; Beltrán-Peña, E.; Herrera-Estrella, A.; López-Bucio, J. Trichoderma-induced plant immunity likely involves both hormonal- and camalexindependent mechanisms in Arabidopsis thaliana and confers resistance against necrotrophic fungus Botrytis cinerea. Plant Signal. Behav. 2011, 6, 1554-1563. [CrossRef]

89. Amselem, J.; Cuomo, C.A.; Van Kan, J.A.L.; Viaud, M.; Benito, E.P.; Couloux, A.; Coutinho, P.M.; De Vries, R.P.; Dyer, P.S.; Fillinger, S.; et al. Genomic Analysis of the Necrotrophic Fungal Pathogens Sclerotinia sclerotiorum and Botrytis cinerea. PLoS Genet. 2011, 7, e1002230. [CrossRef] [PubMed]

90. Estrada-Rivera, M.; Angel, M.; Dautt-Castro, M.; Arenas-Huertero, C.; Herrera-Estrella, A.; Casas-Flores, S. IPA-1 a Putative Chromatin Remodeler/Helicase-Related Protein of Trichoderma virens Plays Important Roles in Antibiosis Against Rhizoctonia solani and Induction of Arabidopsis Systemic Disease Resistance. Mol. Plant-Microbe Interact. 2020, 33, 808-824. [CrossRef] [PubMed]

91. Bateman, A. UniProt: A worldwide hub of protein knowledge. Nucleic Acids Res. 2019, 47, D506-D515. [CrossRef]

92. Altschul, S.F.; Gish, W.; Miller, W.; Myers, E.W.; Lipman, D.J. Basic local alignment search tool. J. Mol. Biol. 1990, 215, 403-410. [CrossRef]

93. Potter, S.C.; Luciani, A.; Eddy, S.R.; Park, Y.; Lopez, R.; Finn, R.D. HMMER web server: 2018 update. Nucleic Acids Res. 2018, 46, W200-W204. [CrossRef]

94. Almagro Armenteros, J.J.; Tsirigos, K.D.; Sønderby, C.K.; Petersen, T.N.; Winther, O.; Brunak, S.; von Heijne, G.; Nielsen, H. SignalP 5.0 improves signal peptide predictions using deep neural networks. Nat. Biotechnol. 2019, 37, 420-423. [CrossRef]

95. Krogh, A.; Larsson, Ė; Von Heijne, G.; Sonnhammer, E.L.L. Predicting Transmembrane Protein Topology with a Hidden Markov Model: Application to Complete Genomes. J. Mol. Biol. 2001, 305, 567-580. [CrossRef]

96. Daudi, A.; O’Brien, J.A. Detection of Hydrogen Peroxide by DAB Staining in Arabidopsis leaves. Bio-Protocol 2012, 2, e263. [CrossRef] 